NBER WORKING PAPER SERIES

\title{
WHAT ENDS RECESSIONS?
}

\author{
Christina D. Romer
}

David H. Romer

Working Paper No. 4765

\section{NATIONAL BUREAU OF ECONOMIC RESEARCH 1050 Massachusetts Avenue \\ Cambridge, MA 02138 \\ June 1994}

We thank Laurence Ball, Olivier Blanchard, John Cochrane, Ray Fair, Stanley Fischer, Michael Lee, N. Gregory Mankiw, Julio Rotemberg, and David Wilcox for helpful comments and suggestions, Keith Carlson and John Peterson for providing data, David Reifschneider, Jill Thompson, and David Wyss for assistance with multipliers, and the National Science Foundation for financial support. This paper is part of NBER's research programs in Economic Fluctuations and Monetary Economics. Any opinions expressed are those of the authors and not those of the National Bureau of Economic Research. 


\title{
WHAT ENDS RECESSIONS?
}

\begin{abstract}
This paper analyzes the contributions of monetary and fiscal policy to postwar economic recoveries. We find that the Federal Reserve typically responds to downturns with prompt and large reductions in interest rates. Discretionary fiscal policy, in contrast, rarely reacts before the trough in economic activity, and even then the responses are usually small. Simulations using multipliers from both simple regressions and a large macroeconomic model show that the interest rate falls account for nearly all of the above-average growth that occurs early in recoveries. Our estimates also indicate that on several occasions expansionary policies have contributed substantially to above-normal growth outside of recoveries. Finally, the results suggest that the persistence of aggregate output movements is largely the result of the extreme persistence of the contribution of policy changes.
\end{abstract}

Christina D. Romer

Department of Economics

University of California

Berkeley, CA 94720

and NBER

\author{
David H. Romer \\ Department of Economics \\ University of Califomia \\ Berkeley, CA 94720 \\ and NBER
}




\section{WHAT ENDS RECESSIONS?}

Christina D. Romer and David H. Romer

\section{INTRODUCTION}

The Employment Act of 1946 set as the goal of government economic policy the maintenance of reasonably full employment and stable prices. Yet, nearly fifty years later, economists seem strangely unsure about what to tell policy-makers to do to end recessions. One source of this uncertainty is confusion about how macroeconomic policies have actually been used to combat recessions. In the midst of the most recent recession, one heard opinions of fiscal policy ranging from the view that no recession has ever ended without fiscal expansion to the view that fiscal stimulus has always come too late. Similarly, for monetary policy there was disagreement about whether looser policy has been a primary engine of recovery from recessions or whether it has been relatively unimportant in these periods.

This paper seeks to fill in this gap in economists' knowledge by analyzing what has ended the eight recessions that have occurred in the United States since 1950. In particular, it analyzes whether monetary and fiscal policy have helped or hindered previous recoveries. By quantifying the role of policy, the paper seeks to identify how much of recoveries is attributable to government action, and how much to other factors such as 
self-correction and fortuitous shocks. By determining which policies were the most effective in ending past recessions, the paper tries to discern the likely efficacy of policy today and in recessions to come.

Our main finding is that monetary policy has been the source of most postwar recoveries. While limited fiscal actions have occurred around most troughs, these actions have almost always been too small to contribute much to economic recovery. In contrast, monetary policy has typically moved toward expansion shortly after the start of most recessions and appears to have contributed, on average, almost two percentage points to real GDP growth in the four quarters following the trough. Even accounting for the fact that tight monetary policy before the peak continues to depress the economy for several years, the net effect of monetary policy in ending recessions has been substantial.

We reach this conclusion through a series of steps. Section II analyzes the record of policy actions since 1950 . It shows that both nominal and real interest rates fell by several percentage points before most troughs. In contrast, the ratio of the high-employment surplus to trend GDP typically fell slightly around troughs, but only rarely moved more than a percentage point.

Section III analyzes the sources of these policy changes. It examines the stated motivations of policy-makers to see if the changes in interest rates and in the high-employment surplus during recessions and around troughs were taken largely to end the recessions or for other reasons. We find that nearly all of the monetary changes and most of the fiscal changes were genuinely anti-recessionary. Interestingly, we find that many of the largest discretionary fiscal actions taken in the postwar era, such 
as the 1964 tax cut and the Nixon "New Economic Policy," were not antirecessionary measures, but expansionary actions taken when policy-makers were dissatisfied with the pace of growth.

Section IV examines the likely effects of the anti-recessionary actions we identify. Using estimates of the effects of policy both from our own regressions and from Data Resources Incorporated's forecasting model, we estimate the contributions of monetary and fiscal policy to recessions and recoveries. Although there is substantial variation in the estimates of policies' impact, the results suggest that monetary policy has been crucial in ending recessions, while fiscal policy has contributed very little. ${ }^{1}$

Section $\mathrm{V}$ investigates two additional issues raised by our analysis. The first issue is the overall stabilization record of policy. We argue that there is little evidence that discretionary policy has had a large stabilizing influence, and that there are several important episodes in which expansionary policy has exacerbated fluctuations. The second issue is the persistence of output movements. We find that the component of fluctuations that is due to shifts in monetary and fiscal policy is highly persistent and accounts for a large part of the persistence of overall output movements.

${ }^{1}$ Perry and Schultze (1993) also investigate the sources of recoveries. They reach conclusions generally similar to ours. 


\section{POLICY ACTIONS IN RECESSIONS AND RECOVERIES}

\section{A. Indicators of Policy}

To analyze whether policy could account for recoveries, it is necessary to examine the behavior of policy during recessions and recoveries. We examine two indicators of monetary policy. The first is simply the quarterly change in the nominal federal funds rate. ${ }^{2}$ Throughout much of the postwar period, the federal funds rate has been the primary proximate instrument of monetary policy. And even during periods when it was not, such as the 1950s and 1979-82, the Federal Reserve placed considerable emphasis on "money market conditions" -- that is, changes in nominal interest rates -- in setting policy. Cook and Hahn (1989) and Bernanke and Blinder (1992) document that the Federal Reserve can control the federal funds rate in the short run, and Bernanke and Blinder present a variety of evidence that innovations in the funds rate are largely due to changes in monetary policy.

Our second indicator of monetary policy is the estimated change in the real funds rate. Theory predicts that it is the real rather than the nominal rate that is relevant for economic activity. The fact that expansionary monetary policy lowers nominal interest rates strongly suggests that the Federal Reserve influences real rates. But since expected inflation may change systematically over the course of recessions and recoveries, it is

${ }^{2}$ Unless otherwise noted, all data are from Citibase (Dec. 1993 update). The federal funds rate data for 1950-54 are described in Romer and Romer (1993). 
important to explicitly examine the behavior of real rates.

Our procedure for estimating the real funds rate follows Mishkin (1981). We first compute the ex post real rate as the difference between the nominal rate and the change in the logarithm of the GDP deflator. ${ }^{3}$ We then regress the ex post real rate on a constant, a time trend, the current and the first four lagged values of the nominal rate, and the first four lags of inflation and real GDP growth. ${ }^{4}$ The sample period is 1951:1 to 1993:2. The estimated values of the ex ante real rate are the fitted values of this regression. Figure 1 shows our estimates of the ex ante real federal funds rate, along with the nominal rate.

Our measure of discretionary fiscal policy is the change in the ratio of the high-employment surplus to trend or potential GDP. ${ }^{5}$ This measure is shown in Figure 2. The rationale for using the high-employment surplus is the standard one that it adjusts for the impact of economic activity on

${ }^{3}$ Because the federal funds rate is a very short-term rate, the relevant inflation rate for computing the real rate for a quarter is inflation within that quarter. We therefore compute the ex post real rate for quarter $t$ as $i_{t}$ $4\left[\ln \left(\left(P_{t+1}+P_{t}\right) / 2\right)-\ln \left(\left(P_{t}+P_{t-1}\right) / 2\right)\right]$, where $i$ is the nominal funds rate and $P$ is the GDP deflator.

4 To prevent the period-t value of the GDP deflator from entering the first lag of inflation, the lagged values of inflation are computed simply as $4\left[\ln \left(P_{t-1}\right)-\ln \left(P_{t-2}\right)\right], 4\left[\ln \left(P_{t-2}\right)-\ln \left(P_{t-3}\right)\right]$, and so on, rather than in the more complex way used to calculate current inflation described in $n .3$. Using the more complex definition has essentially no effect on the estimated real interest rate series.

${ }^{5}$ For the period since 1955, the data are from the Congressional Budget Office. The data for 1950-54 are described in Carlson (1987). 
receipts and expenditures. Because of this adjustment, the high-employment surplus can differentiate fiscal actions taken deliberately in response to recessions from those that occur automatically. The high-employment surplus, however, is not a perfect measure of discretionary fiscal changes because some actions may have more or less effect on the economy than their impact on the high-employment surplus would suggest. Therefore, in the analysis of fiscal policy in the next two sections, we discuss temporary tax changes, investment tax credits, and other factors that might cause the change in the high-employment surplus to be a misleading measure of the expansionary stance of fiscal policy.

Although it is useful to separate out the automatic changes in the surplus that are caused by economic activity from the discretionary changes, the automatic changes are nevertheless interesting. It is certainly possible, for example, that automatic stabilizers are important to recoveries. For this reason we also examine the change in the ratio of the automatic surplus to trend GDP; we measure the automatic component of the surplus simply as the difference between the actual surplus and the high-employment surplus. $^{6}$

\section{B. Results}

Monetary Policy. Table 1 reports the behavior of the federal funds rate during recessions -- specifically, from the times of peaks in real GDP

${ }^{6}$ For the actual budget surplus, we use the National Income and Product Accounts measure of the federal surplus. 
to the quarter after troughs. ${ }^{7}$ The top half of the table shows the change in the nominal rate; the bottom half shows the change in the real rate.

The table shows that interest rates fall sharply in recessions. The falls in the nominal funds rate are particularly consistent: 28 of the 33 entries in the top portion of the table are negative. The only significant exception to the pattern of falling nominal rates occurred in 1974, when the Federal Reserve moved to sharply tighter policy even though real output was falling. Even during this recession, however, the overall movement in the funds rate was a large decline. The average decline between the peak in output and one quarter after the trough is 3.4 percentage points. For comparison, the standard deviation of movements in the nominal funds rate for the full sample is 1.0 percentage points for one-quarter changes, and 2.3 percentage points for four-quarter changes. Thus the declines in recessions are large.

The bottom half of the table shows that real interest rates also fell during these recessions. In all eight episodes, the estimated real rate fell between the peak and the quarter after the trough. The declines in the real rate are somewhat smaller and less consistent than the falls in the nominal rate, however. For example, the average decline is just slightly over 2 percentage points. ${ }^{8}$

${ }^{7}$ Because our focus is on movements in aggregate output, we use the dates of the peaks and troughs in real GDP rather than NBER peaks and troughs. The two sets of dates are very similar, however.

${ }^{8}$ Section IV.C shows that the declines in output, prices, and expected inflation during recessions relative to their normal behavior would have caused only small falls in nominal interest rates, and essentially no change 
Once a recovery has begun, there is a moderate tendency for both the nominal and real funds rates to rise. Table 2 shows the changes in the nominal and real federal funds rates in the second through fifth quarters after troughs. About two-thirds of these entries are positive, with an average rise of both the nominal and the real rate during these periods of about one percentage point. And although the relevant numbers are not reported in the tables, the same general tendency toward moderate interest rate increases continues through the second year of recoveries. Table 2 also shows that the 1991 experience is quite unusual. Rather than rising as is typical, both real and nominal rates fell substantially after the trough.

This examination of movements in interest rates suggests that monetary policy could play a critical role in recoveries: there are large, consistent declines in interest rates during recessions. Whether these declines reflect deliberate countercyclical policy, and whether their timing and magnitude are consistent with the view that they are important in recoveries, are questions that we address in the next two sections.

Fiscal Policy. Table 3 reports the change in the ratio of the highemployment surplus to trend GDP from peaks to five quarters after troughs. These data do not show any pattern of discretionary fiscal policy as consistent or strong as the declines in interest rates in recessions. The average cumulative change in the high-employment surplus to GDP ratio

in real rates, if the Federal Reserve had kept the money growth rate fixed in the face of these movements. Thus even if we adopted measures of monetary policy that did not attribute these parts of changes in interest rates to policy, we would still find that monetary policy was the source of the bulk of the interest rate declines. 
from the peak to one quarter after the trough is -0.7 percentage points. However, there is great variation around this average, with some cumulative changes being large and positive, and others being large and negative. To put the average change in perspective, the standard deviation of movements in the high-employment surplus to GDP ratio for the full sample is 0.6 percentage points for one-quarter changes and 1.1 percentage points for four-quarter changes. Thus the average fall during recessions is not large relative to typical movements in the high-employment surplus to GDP ratio.

To the extent that there is any systematic pattern in deliberate fiscal policy, it is that policy is generally expansionary around troughs. For example, in every recession except the one immediately after the Korean War, the ratio of the high-employment surplus to GDP fell between two quarters before the trough and the quarter after the trough; 19 of the 24 individual changes for these quarters were negative. The overall shifts over these three quarters were generally about one percent of GDP. Thus it does appear that fiscal policy becomes slightly expansionary late in recessions.

The record of automatic fiscal policy is decidedly more promising than that of discretionary fiscal policy. Table 4 shows the change in the automatic surplus to GDP ratio around the eight troughs since 1950. As would be expected, the automatic surplus to GDP ratio consistently declines during recessions. These automatic falls in the surplus are moderately large; the average cumulative decline in the automatic surplus to GDP ratio from the peak to the quarter after the trough is 1.6 percentage points. For comparison, the standard deviation of changes in the automatic surplus to GDP ratio is 0.3 percentage points for one-quarter changes and 0.9 
percentage points for four-quarter changes.

This simple examination of the data suggests that automatic fiscal policy is more likely to have affected recoveries than has discretionary policy. Unless the effects of modest changes in deliberate fiscal policy are large or there are consistently important shifts in fiscal policy that are not reflected in the high-employment surplus, discretionary fiscal policy cannot have played a central role in ending downturns or in creating strong recoveries. On the other hand, the automatic movements in the surplus during recessions may be large enough and consistent enough to have significantly affected the path of real output following troughs.

Despite this negative conclusion on the overall movement of discretionary fiscal policy during recessions, the finding that discretionary fiscal policy is consistently expansionary around troughs is intriguing. If these expansions are in fact responses to economic conditions, they would suggest that deliberate fiscal policy may play some role in recoveries. More important, they raise the possibility that if such expansions were only undertaken more aggressively, fiscal policy could be a significant countercyclical tool. The key issues are the motives for the shifts in policy, the reasons they are not larger, and the timing of their effects. It is to these issues that we now turn.

\section{MOTIVATIONS FOR POLICY ACTIONS}

This section analyzes the nature and motivation of the policy actions behind the movements in interest rates and the high-employment surplus 
described in the previous section. This analysis is crucially important because our policy indicators could move for reasons other than antirecessionary policy. Interest rates, for example, could decline during recessions if the Federal Reserve were targeting money growth and simply allowed rates to fall as declines in real activity reduced money demand. They could also fall if the Federal Reserve were targeting interest rates but changed them in response to international or financial-market developments rather than in response to recessions. Similarly, the high-employment surplus could fall because of military actions or other spending changes unrelated to the state of the economy. Only by analyzing the motivations of policy-makers can we determine whether the movements in interest rates and the high-employment surplus during recessions were the result of deliberate anti-recessionary policy.

\section{A. Monetary Policy}

The records of the Federal Reserve provide ample evidence that the falls in interest rates before recoveries are the result of deliberate antirecessionary policy. Boschen and Mills (1992) provide a monthly index of the Federal Reserve's intentions based on the Record of Policy Actions of the Federal Open Market Committee. Their index classifies intentions on a scale from -2 to +2 , with -2 indicating a strong emphasis on inflation reduction and +2 indicating a strong emphasis on real growth. Table 5 shows the change in the Boschen-Mills index from the peak in economic activity to five quarters after the trough. (Most of the values are in fractions because we have converted the monthly series to quarterly values to be consistent with our other indicators.) 
The most obvious message of Table 5 is that monetary policy typically changes toward an emphasis on real growth very soon after the peak in real GDP. Without exception, the change in the Boschen-Mills index is positive within two quarters of the peak. In many cases the change occurs concurrent with or even slightly before the peak in output. This pattern obviously parallels the finding in Section II that interest rates fall soon after the peak in most cases. The behavior of the Boschen-Mills index indicates that the Federal Reserve typically responds to weakness in the economy quite rapidly, and that the declines in interest rates are generally the result of deliberate monetary policy.

Table 5 also shows that the emphasis of monetary policy typically changes soon after the trough. In every recession analyzed by Boschen and Mills, monetary policy turned contractionary within two or three quarters of the low point in real output. This again suggests that the rises in interest rates after troughs described in Section II are the result of deliberate Federal Reserve policy. ${ }^{9}$

\section{Episodes}

The Boschen and Mills index, while very useful, is not perfect for our purposes because it does not consider the Federal Reserve's perceptions

${ }^{9}$ It is important to note that although Boschen and Mills find that concern about inflation became the main motivational factor for the Federal Reserve after each trough, inflation itself does not consistently rise in the early stages of the recoveries. To the extent that there is a pattern, the inflation rate (measured as the percentage change in the GDP deflator) generally falls during the first two years of recoveries, though most of this effect is due to the first quarter after the trough. 
of the state of the economy. ${ }^{10}$ It therefore does not distinguish between times when the Federal Reserve is counteracting a recession and, for example, times when it believes the economy is growing normally but desires even faster growth. For this reason, it is useful to supplement Boschen and Mills's analysis with an independent reading of the Record of Policy Actions of the Federal Open Market Committee and the Minutes of the FOMC during recessions. ${ }^{11}$

1953. The Federal Reserve was very quick to perceive the weakening of the economy in 1953. In retrospect, we know that the peak in real GDP occurred in the second quarter of 1953. Yet as early as the June 11, 1953 meeting, one member of the FOMC expressed the opinion that "the economy was cresting" (Minutes, 6/11/53, p. 50). Throughout the fall, the economic conditions reviewed by the Board indicated that the economy was relatively stable, but with "indications of reductions in demand in some important sectors" (Minutes, 9/8/53, p. 2). By December, however, the FOMC felt that "the decline in economic conditions, though moderate, was unmistakable" (1953, p. 102). The FOMC began to loosen policy in the summer of 1953 . The FOMC initially aimed merely to end the previous policy of monetary contraction, but by September 1953 they had adopted a

${ }^{10}$ The speed with which the Federal Reserve recognizes recessions has been analyzed by other researchers. See, for example, Hinshaw (1968), Karaken and Solow (1963), and Brunner and Meltzer (1964).

11 The Records of Policy Actions for each year are compiled in the Annual Reports of the Board of Governors. Citations to this source are only identified by the year and page number. Citations to the Minutes are identified by the title, date, and page number. 
program of "active ease." The motivations for this policy were summed up by one member who stated that:

the System should be trying to build factors which would offset any down-turn in the economy .... [Thus] it would be desirable to pursue a policy of active ease by putting reserves liberally into the market (Minutes, 9/8/53, p. 11).

This switch to anti-recessionary policy is also indicated by the decision to remove any mention of inflation from the directive, leaving as the primary goal of open market operations "avoiding deflationary tendencies" (Minutes, $9 / 24 / 53$, p. 29$).^{12}$

1957. Monetary policy in 1957 was almost identical to that in 1953. Once again, the Federal Reserve perceived the downturn immediately. While the peak in real GDP occurred in the third quarter of 1957, the records of the Federal Reserve show that as of the October 1, 1957 meeting the FOMC noted that "an increasing number of business observers were suggesting ... that the prospective movement in activity was a decline" (1957, p. 51). By the November 12 meeting, the FOMC perceived that "there no longer was much doubt that at least a mild downturn in business activity was under way" (1957, p. 56). In response to the decline, on November 12 the FOMC changed its policy directive

to eliminate the previous clause (b) which had called for restraining inflationary pressures and to replace that clause

${ }^{12}$ Technical considerations involving seasonal demand for reserves and Treasury financing operations had some effect on the exact timing of the easing over this period. Specifically, these considerations appear to have led the FOMC to ease slightly more in June and September, and slightly less in December. 
with wording that provided for open market operations with a view ... "to fostering sustainable growth in the economy without inflation by moderating the pressures on bank reserves" (1957, p. 56).

The motivation for this change was summed up by Vice Chairman Hayes, who stated that "relaxing credit restraint ... seems desirable in view of the possibility, however remote, that the business adjustment may be more than a mild dip" (Minutes, 11/12/57, p. 18). Thus monetary policy was clearly anti-recessionary in this episode.

1960. The changes in monetary policy during the 1960 recession were motivated largely by a belief that economic activity was roughly constant or increasing slightly, not by perceptions that the economy was in a recession. While the peak in real GDP occurred in the first quarter of 1960, as late as July 1960 the FOMC's perception was only that "little upward momentum was evident, ... and uncertainty regarding future trends continued to be widespread" $(1960$, p. 58$)$. The Federal Reserve nevertheless moved to lower interest rates repeatedly over the first nine months of the year in order to increase real growth. For example, in May the FOMC felt that the "lack of exuberance in the business picture ... justified moving modestly in the direction of increasing the supply of reserves available to the banking system" (1960, p. 53). It was not until November that the FOMC realized that a recession was under way (1960, pp. 70-71). By that time, however, balance of payments considerations prevented further easing. Thus the declines in interest rates over this period were largely the result of shifts in policy in response to news about real output, but were not truly anti-recessionary.

1969. Real output reached its peak in the fourth quarter of 1969. 
Over the last several months of 1969 , the Federal Reserve gradually revised its forecast of short-run growth downward to the point where its expectation was that growth would be approximately zero over the next several quarters. Concern about the high level of inflation, however, kept the FOMC from shifting to easier policy (see, for example, 1970, p. 96). By February 1970 the forecast had been revised to predict negative growth; as a result, the FOMC "concluded that, in light of the latest economic developments and the current business outlook, it was appropriate to move gradually toward somewhat less restraint" (1970, p. 103). The stance of policy actually shifted only slightly over the next several months, however. But beginning in May, the FOMC moved consistently toward easier policy. In May and June, this shift was to some extent a response to "strains" in financial markets. Throughout the second half of the year, however, the easing was a response to the weak state of the economy and a perception that inflation was moderating. In August, for example, the FOMC felt that

expectations of continuing inflation had abated considerably .... It was the consensus of the Committee that monetary policy at present should be sufficiently stimulative to foster moderate growth in real economic activity .... Against this background, the Committee decided that open market operations should be directed at promoting some easing of conditions in credit markets (1970, p. 149).

Thus the falls in interest rates during the 1969 recession were largely the result of deliberate anti-recessionary policies.

1973. Beginning in roughly February 1974, the Federal Reserve expected real output to fall in the first quarter and then to stay essentially unchanged (see, for example, 1974, pp. 137, 144). While this suggests that 
the Federal Reserve was quick to discern the onset of recession, which we now date as having begun with the peak in the fourth quarter of 1973 , it was slow to realize its severity. It was not until the October 14 FOMC meeting that the System acknowledged that there would be an extended decline in real activity (1974, p. 207). As in 1969-70, concern about inflation prevented the Federal Reserve from loosening significantly during the early part of the recession, and in fact led to considerable tightening in the spring of 1974 (see, for example, 1974, pp. 107, 161). Beginning in September, however, the FOMC began to move to ease policy significantly. This easing was clearly a response to the recession; for example, the summary of actions by the Board of Governors in September through November states that

the Board felt that the weakening tendencies in the economy should be countered initially through the use of monetary policy instruments other than the discount rate. To this end, System open market operations became increasingly less restrictive as the fall progressed (1974, pp. 109-110; see also pp. 202-203, 211, 213, 225).

These anti-recessionary policies continued into the first part of 1975 (see for example 1975, pp. 142-143).

1980. At every meeting of the FOMC from July 1979 through the summer of 1980, the Federal Reserve believed that a recession was either under way or was imminent. Concern about inflation and money growth, however, prevented policy-makers from moving to lower interest rates until the spring of 1980. Beginning in April 1980, just after the actual peak in real GDP in the first quarter of 1980 , the combination of weak money growth and unfavorable news about real output caused the FOMC to lower the federal funds rate sharply. The FOMC did not want to "exacerbate 
recessionary tendencies in the economy" and was concerned about "the risk that the contraction would prove to be deeper than was widely expected" (1980, pp. 117, 122).

1981. Real GDP peaked in the third quarter of 1981. As early as November, "the consensus [of the FOMC] was that the downward drift in economic activity apparent when the Committee met in early October had clearly developed into a recession" (1981, p. 136). The major declines in interest rates occurred in the fourth quarter of 1981 and in the third and fourth quarters of 1982. The declines in late 1981, like those in the spring of 1980 , were partly a response to weak money growth and partly a direct response to the recession. By July 1982, the FOMC wanted "to provide sufficient monetary growth to encourage recovery in economic activity over the months ahead" (1982, pp. 109-110). FOMC members stressed "the need for flexibility in interpreting the behavior of the monetary aggregates," and felt that money growth "near, or for a time somewhat above, the upper ends of [the target] ranges would be acceptable" (1982, p. 111). Although concern with the growth of monetary aggregates was an important motive in monetary policy over this period, direct concern about real activity and the effects of the recession on the financial system was important as well.

1990. In the most recent recession the Federal Reserve began to worry about a downturn long before it occurred. As early as December 1989, the FOMC viewed "the risks of a shortfall in economic activity as sufficiently high to justify an immediate move to slightly easier reserve conditions" $^{n}$ (1989, pp. 135-136). In July 1990, immediately after what we now know was the peak in real GDP, the FOMC expected "sustained but subdued growth in economic activity ... for the next several quarters" (1990, 
p. 120). In response they called for "some easing fairly soon unless incoming indicators indicated appreciably stronger monetary growth and greater inflationary pressures than the members currently expected" (1990, p. 126). While the Federal Reserve was quick to worry about recession, it was fairly slow to realize that a recession was actually in progress during the fall of 1990 . In October the FOMC believed that "the available data do not point to cumulating weakness and the onset of a recession" (1990, p. 139). They nevertheless felt that "an easing move was warranted in light of indications that there was a significant risk of a much weaker economy" (1990, p. 141). Not until November did a consensus develop that "the most likely outcome was a relatively mild and brief downturn" (1990, p. 148). At this point, the FOMC voted for some slight immediate easing of reserve conditions and indicated that "the growing signs of a softening economy ... suggested that the Committee should remain alert ... to signals that some further easing was appropriate" (1990, p. 149). Thus it appears that, although the falls in interest rates throughout 1990 were motivated by movements in real output, only those after November 1990 were truly antirecessionary.

\section{Lessons from Postwar Monetary Policy}

This analysis of the motivations for policy suggests that monetary policy can respond quickly to changes in economic conditions. The Federal Reserve has almost always recognized that a recession was underway very rapidly. Only in 1960 and 1990 was there a lag of more than one quarter between the peak and when the Federal Reserve perceived a downturn. And even in these two instances the Federal Reserve loosened in response 
to what it perceived as merely slow growth.

In most instances the Federal Reserve responded to the weakening economy by increasing reserves immediately. This suggests that the declines in interest rates during recessions documented in Section II were at least partly the result of anti-recessionary monetary policy. In those instances where policy-makers did not cut interest rates in response to the weakening of the economy, it was typically because some other factor, such as inflation or balance of payments difficulties, was thought to necessitate tight policy.

The fact that the Boschen and Mills index of Federal Reserve intentions shows a move toward inflation control soon after the start of most recoveries is also important. It suggests that most periods of high inflation are not the result of anti-recessionary monetary policy carried too far. Rather, they are more likely the result of expansionary policies taken for reasons unrelated to recessions or of insufficient shifts toward combating inflation once recoveries have begun. Thus policy mistakes are not an inherent feature of anti-recessionary monetary policy.

\section{B. Fiscal Policy}

Our primary source for the history of fiscal policy is the Economic Report of the President, published biennially from 1948 to 1952 and then annually from 1953 through the present. The Economic Reports contain detailed descriptions and justifications of the President's fiscal policy recommendations. They also summarize the fiscal policies actually implemented in the preceding year. If the policies implemented differ from those previously recommended by the Administration, some discussion or critique of Congress's motives is usually given. As a result, the Economic 
Reports provide unique insight into both the motivation for policy and the lags in taking fiscal actions. ${ }^{13}$

\section{Episodes}

1953. The end of the Korean War caused a substantial decline in government spending in 1953. When a recession began in the second quarter of 1953, the Eisenhower administration did not take any noticeable steps to increase spending. It did, however, move to reduce taxes shortly before the trough of the recession in the second quarter of 1954. In January 1954 an extensive tax cut went into effect that reduced taxes during the first six months of 1954 by $\$ 1.1$ billion, or about $0.6 \%$ of GDP over this period (1955, p. 19). This tax cut eliminated two wartime tax increases: the excess profits tax passed in 1950, and the personal and corporate income tax increases put into place in 1951.

Whether this fiscal action was truly anti-recessionary is ambiguous because the original legislation called for the excess profits tax to expire on June 30, 1953 and the personal income tax increase to be rescinded on December 31, 1953. Three pieces of evidence, however, suggest that it was largely discretionary. First, the excess profits tax was extended for six months early in 1953 at the urging of President Eisenhower, who felt that a tax cut in mid-1953 would be inflationary. Second, the 1953 Economic Report includes among its 1954 budget deficit projections, the situation that would occur "if the post-Korea tax increases are not allowed to run off as

13 Unless otherwise noted, all citations in this section refer to the Economic Reports. 
provided by present law" (1953, p. 71). This suggests that the Truman administration thought an extension of the wartime taxes was a likely outcome. Finally, the Eisenhower Economic Report of 1954 treats the tax decrease as an important anti-recessionary act. It states:

The Secretary of the Treasury therefore announced in the plainest possible language that the Administration, besides relinquishing the excess-profits tax, would not seek to postpone the reduction of the personal income tax, averaging approximately 10 percent, scheduled for January 1, 1954. This unequivocal promise of tax relief to both families and business firms bolstered confidence at a time when trade and employment were slipping slightly. In coming months these well-timed tax reductions are likely to give substantial support to consumer and investment markets (1954, p. 52).

Even if the tax reduction was discretionary, it is obvious that this is an unusual case. The President rarely has a tax cut passed and waiting prior to the onset of recession. Thus there was more flexibility in fiscal policy in 1953 than at almost any other time. ${ }^{14}$

1957. The 1957 recession began in the third quarter of 1957 . The only significant fiscal change that occurred soon after the onset of the recession was an acceleration of defense spending. The Eisenhower administration accelerated the placement of defense contracts, and in January 1958 requested supplemental appropriations of $\$ 1.3$ billion from

${ }^{14}$ Despite the reduction in taxes, the high-employment surplus to GDP ratio actually rose slightly in 1954 because of an even greater reduction in spending. However, since the decline in expenditures reflected both external shocks and long-term national security planning, it seems reasonable to view fiscal policy as quite expansionary in 1954 relative to likely alternatives. 
Congress as an advance on 1959 spending. Although the Administration stressed that national security was the main motivation for these actions, it was quick to point out the economic benefits. For example, the 1958 Economic Report states:

At the turn of the year, the economy was beginning to feel the effects of an acceleration of the placement of defense contract awards, prompted by the need to move forward quickly with programs essential to the strengthening of the Nation's defenses $(1958$, p. 8).

The frequent references to the economic benefits of this spending suggests that at least some of the motivation was anti-recessionary.

The 1959 Economic Report indicates that similar types of spending acceleration were undertaken around the trough in the first quarter of 1958. In March and April 1958, spending on federal programs for building airports, hospitals, and other public buildings was moved forward. In April 1958, legislation was passed to increase spending on the interstate highway program (1959, pp. 41-42). Both of these measures were consistent with the Eisenhower philosophy that

the major emphasis of Federal countercyclical policy should be placed on measures that will result in prompt action .... Though a useful contribution can be made by the acceleration of public works projects that are already under way or are ready to be started, little reliance can be placed on large undertakings which ... can be put into operation only after an extended interval of planning" $(1959$, p. 2).

In addition to these measures, Congress passed, at the Administration's request, a temporary extension of unemployment benefits in June 1958 $(1959$, p. 40). Several minor spending bills passed in July 1958 were also taken at least partly in response to the state of the economy (Bartlett, 1993). 
1960. Real GDP peaked in the first quarter of 1960. The 1961 Economic Report indicates that no significant anti-recessionary fiscal actions were taken before the trough in the fourth quarter of 1960. Numerous actions, however, were taken in the quarter just after the turning point in GDP. The first Kennedy administration Economic Report in January 1962 reports that "immediately upon taking office, the new Administration moved vigorously to use the fiscal powers of the Federal Government to help bring about economic recovery" (1962, p. 82). Among the measures proposed and quickly passed were an acceleration of federal procurement and tax refunds, changes in transfer programs that added $\$ 2$ billion to transfer payments over fiscal years 1961 and 1962 combined, and the Temporary Extended Unemployment Compensation Act, which extended coverage. ${ }^{15}$ Despite this flurry of activity, the total amount spent under these programs was quite small.

An investment tax credit equal to $7 \%$ of gross investment in depreciable machinery and equipment was also proposed early in the Kennedy administration, and was passed in October 1962. Interestingly, this action is discussed in the chapter of the Economic Report on policies to encourage economic growth, not in the chapter on economic recovery. The 1962 Report states that "if faster economic growth is desired, revision of the

15 Two other measures, the Area Redevelopment Act enacted in May 1961 and the Public Works Acceleration Act enacted in September 1962, were designed to aid areas with particularly high and persistent unemployment. Whether these programs should be viewed as antirecessionary acts or general anti-poverty measures is unclear. However, neither program was very large. 
tax structure is called for, to permit a higher rate of investment once full use of resources is achieved" (1962, p. 132). While the Report points out that increased investment will stimulate aggregate demand, this does not seem to be the primary motivation behind the program. Thus this often noted Kennedy fiscal stimulus appears to have been primarily motivated not by the 1960 recession, but rather by supply-side issues related to long-term growth.

The motivation for the even more famous 1964 tax cut appears to be a mixture of concern about sluggish growth and concern about incentives. It is clear from the 1963 Economic Report, which contains the first discussion of this proposed tax reduction, that the act was not some grossly delayed response to the 1960 recession. The Report states that "we approach the issue of tax revision, not in an atmosphere of haste and panic brought on by recession or depression, but in a period of comparative calm" (1963, p. xiii). The Report goes on to argue that:

Only when we have removed the heavy drag our fiscal system now exerts on personal and business purchasing power and on the financial incentives for greater risktaking and personal effort can we expect to restore the high levels of employment and high rate of growth that we took for granted in the first decade after the war (1963, p. xv).

While supply-side effects are certainly emphasized, there is sufficient discussion of under-utilized capacity and unemployment in the 1963 and 1964 Economic Reports that it seems clear that the aggregate demand effects of the tax cut were also a major factor in the proposal, and in the ultimate passage of the act in February 1964.

1969. Real output peaked in the third quarter of 1969 . The 1970 Economic Report makes it clear that inflation was such an overriding 
concern that the Administration resisted efforts by Congress to increase spending or reduce taxes. It states: "the best hope of curbing inflation and restricting the rise in unemployment ... rests with a policy of firm and persistent restraint on the expansion in the demand for goods, services, and labor" $(1970$, p. 22$)$. The one obviously anti-recessionary measure that was proposed (and ultimately passed in August 1970, shortly after the trough in output) was the Employment Security Amendments, which provided additional unemployment benefits once the insured unemployment rate exceeded $41 / 2 \%$ for 3 consecutive months.

In 1971 the Administration sought to run a balanced fullemployment budget. The 1971 Economic Report indicates that the Administration "strongly resisted program expansion which would substantially raise commitments for expenditures beyond 1970 " (1971, p. 26), and took no fiscal measures aimed at stemming the recession. There were some increases in transfer payments because of a change in social security benefits and an increase in revenue-sharing to the states, but neither of these measures appears to have been related to the state of the economy. Therefore, any fall in the high-employment surplus in 1970 and 1971 was motivated by considerations other than the recession. ${ }^{16}$

${ }^{16}$ One ambiguity in the 1970 fiscal record concerns the $10 \%$ income tax surcharge implemented in 1968 . This surcharge, which was set to expire on June 30, 1969, was extended in August at the urging of the President to cover the last 6 months of 1969. In December Congress approved a reduction of the surcharge to 5\% and an extension to June 30,1970. Given this record of extensions, the failure to extend the surcharge in mid-1970 could be viewed as an anti-recessionary policy. However, the 1970 Economic Report does not speak of the expiration in this way. It states that 
In August 1971, more than a year after the trough in the second quarter of 1970, the Nixon administration proposed the "New Economic Policy." This proposal called for an end to gold convertibility, a $10 \%$ surcharge on imports, a wage and price freeze, and a substantial fiscal expansion. Among the fiscal changes that were passed by Congress in 1971 were an increase in the personal income tax exemption, the removal of some excise taxes, a 7\% job development credit, and the reinstatement of the investment tax credit. According to Carlson (1981), the Revenue Act of 1971 reduced annual tax revenues by $\$ 8$ billion, or $0.7 \%$ of GDP. The 1972 Economic Report makes clear that the Administration was well aware that the economy was already recovering before the New Economic Policy was proposed. It states: "[The Administration] believed that a more rapid expansion of the economy than was generally forecast was desirable and

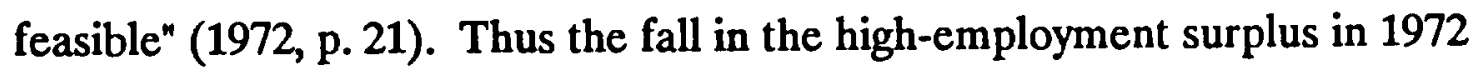
was motivated not by an attempt to end a recession, but by a desire for more rapid growth.

1973. Real GDP peaked in the fourth quarter of 1973. The immediate response of the Administration was to do nothing. According to the 1974 Economic Report, "the budget proposed by the President ... would inject no fiscal stimulus to push the economy above its average rate of

"the tight expenditure control recommended for the budget for fiscal 1971 ... is intended to prevent [excessive stimulus caused by the expiration of the tax surcharge]" (1970, p. 59). 
expansion" (1974, p. 29). ${ }^{17}$ By January 1975, shortly before the trough in real GDP, the Administration perceived that the economy was in a severe recession and proposed a one-year tax cut of $\$ 16$ billion. The Economic Report for this year refers to it as an "anti-recession tax cut" $(1975$, p. 7), and it is clear that there was no motivation other than the recession. The Tax Reduction Act of 1975 was passed by Congress in March 1975. The largest component of this act was a rebate of approximately $10 \%$ of 1974 personal income taxes, which was paid in May and September 1975. The act also lowered individual income taxes for 1975 by increasing the standard deduction and by granting a $\$ 30$ credit to each taxpayer. The act also reduced corporate liabilities by a substantial amount, mainly through an increase in the investment tax credit from $7 \%$ to $10 \%$.

There were minor spending changes in 1975 as well. The 1975 Economic Report states that "in response to the sharp rise in unemployment in the second half of 1974, two new laws that affect the unemployment insurance program were enacted in December 1974" (1975, p. 120). The Emergency Unemployment Compensation Act extended unemployment insurance by 13 weeks, and the Emergency Jobs and Unemployment Assistance Act gave unemployment benefits to some uncovered workers and provided for a small public service employment program. These programs were entirely motivated by the recession. The only major change in spending that was not unambiguously anti-recessionary was a $7 \%$ increase

${ }^{17}$ The 1975 Economic Report states that fiscal policy in 1974 was more contractionary than anticipated because of the revenue-increasing effects of inflation $(1975$, p. 60). 
in social security benefits passed in April 1974. Taken as a whole, antirecessionary fiscal policy actions were very large in 1975 and explain most of the fall in the high-employment surplus in this year.

The Revenue Adjustment Act of 1975 extended most of the personal and corporate tax cuts included in the Tax Reduction Act of 1975 through the first six months of 1976 . The 1977 Economic Report states that "the objective of fiscal policy in 1976 was to maintain the degree of stimulus provided during 1975 in order to keep the economy on a course of moderate, sustained expansion" (1977, p. 69). The Tax Reform Act of 1976 extended many of the 1975 tax changes through 1977. The Ford administration argued in favor of a permanent extension, and even called for larger tax cuts, on the grounds that the changes would stimulate investment and long-term growth (1977, pp. 4-5). Thus it appears that by mid-1976 the motivation for policy had shifted from anti-recessionary considerations to a desire to stimulate long-run economic progress.

According to the first Carter administration Economic Report in January 1978, the Administration "proposed a series of measures intended to raise the rate of growth of real output in 1977 and 1978 to a pace that would lead to significant reductions in the unemployment rate" (1978, p. 50). Among the actions taken were the Tax Reduction and Simplification Act of 1977, which led to net tax reductions of roughly $\$ 5$ and $\$ 10$ billion in 1977 and 1978, respectively, largely through increases in the personal standard deduction and an employment tax credit. A variety of public works, public service employment, and training programs were funded by the Economic Stimulus Appropriations Act in the spring of 1977 and were aimed at stimulating the economy. These spending increases amounted to roughly 
$\$ 1$ billion in 1977 and $\$ 7$ billion in 1978. The motivation for all of these programs was clearly to increase growth from an already moderate level. For example, the President's section of the 1978 Economic Report states that "I have begun from the premise that our economy is basically healthy," and that the "American economy is completing three years of recovery from the severe recession of $1974-75^{\prime \prime}(1978$, p. 3).

1980. The 1980 recession began in the first quarter of 1980 and ended in the second. The Carter administration, apparently chastened by increases in inflation during its first years in office, took no expansionary fiscal actions in response to the downturn. The 1981 Economic Report states:

twice in the last decade the tendency for government to stimulate the economy somewhat too freely during the recovery from recession probably played a role in retarding the decline of inflation or renewing its acceleration. That is why I was so insistent that a tax cut designed for quick economic stimulus not be enacted last year (1981, p. 8).

In fact, inflation was seen as such an overriding problem that Carter proposed tightening fiscal policy in January 1980, when the Economic Report noted "that a mild recession is widely forecast" (1980, p. 9). The Administration believed that "this austere budget policy, accompanied by supportive policies of monetary restraint, is a necessary condition for controlling inflation" $(1980$, p. 6$) .^{18}$

18 The 1981 Economic Report emphasizes that the fall in the highemployment surplus in 1980 was not deliberate. Rather, it was due to the "delayed effect on individual tax refunds and final settlements from the Revenue Act of $1978^{\text {" }}$ and "to large increases in interest outlays caused by record high interest rates" (1981, pp. 156-157). 
1981. Following a brief recovery in the late 1980 and early 1981 , the economy slipped into another recession in the third quarter of 1981 . This recession lasted until the third quarter of 1982 . Fiscal policy changes in the first year of the Reagan administration were enormous. The Economic Recovery Tax Act of 1981 reduced both personal and business taxes substantially. In addition to the tax reductions, federal spending rose substantially, mainly because of increases in real national defense purchases (as measured by the National Income and Product Accounts) of 6\% in 1981 and $7 \%$ in 1982.

Despite its name, the Economic Recovery Tax Act of 1981 appears not to have been motivated by the recession. The 1982 Economic Report states that "the major elements of the Administration's economic policy are designed to increase long-term growth and to reduce inflation. Uniformly favorable near-term effects were not expected" (1982, p. 24). It specifically identifies the Economic Recovery Tax Act as one of those long-term policies, and the short-term stimulatory effects are never mentioned (1982, p. 44). Even the 1984 Economic Report only mentions the aggregate demand effects of the tax cut in the context of discussing why the deficit is not an immediate danger to the economy $(1984$, p. 39$)$.

There is similarly little emphasis on the short-term stimulatory effects of the increase in defense expenditures. The 1982 Economic Report makes it clear that national security was the main motive behind the spending program when it states that "any economic effects, however, must be assessed in the context of the overriding need for maintaining the level of defense spending necessary for national security" (1982, p. 85). Furthermore, the main short-term effects that were contemplated were 
bottlenecks and price increases in industries that supply defense goods (1982, p. 86). Thus it appears that fiscal changes in 1981-82 were almost entirely motivated by factors other than the recession.

1990. The most recent recession began in the second quarter of 1990 and ended in the first quarter of 1991 . Fiscal policy was essentially unchanged during the recession. One explanation for this absence of discretionary fiscal policy is that the Omnibus Budget Reconciliation Act had been passed in November 1990. Given its stress on "credible and systematic" policies (1991, p. 4), the Bush administration did not want to change fiscal policy so soon after the budget agreement. ${ }^{19}$ The only significant fiscal action proposed in 1991 was a cut in the tax rate on long-term capital gains, and this measure was defeated in Congress.

According to the 1993 Economic Report, "when the need for a fiscal policy that would provide immediate stimulus became increasingly clear in late 1991," the Bush administration proposed several small fiscal changes (1993, p. 51). Among the measures taken were executive actions to reduce personal income tax withholding and to accelerate the spending of previously appropriated Federal funds. Legislation to reduce the capital gains tax, to provide for a temporary investment tax allowance, to enhance depreciation for certain companies, and to provide for a temporary tax credit for firsttime homebuyers was also proposed. None of these programs were very large, however, and none were passed by Congress.

${ }^{19}$ The 1993 Economic Report states that "the Budget Enforcement Act of 1990 , the ongoing defense downsizing, and a political stalemate between the Administration and the Congress played important roles in keeping fiscal policy from being more stimulativen (1993, pp. 55-56). 


\section{Lessons from Postwar Fiscal Policy}

This analysis of the motivations of policy suggests some important facts about postwar fiscal policy. First, there is abundant evidence that limited fiscal stimulus can be undertaken rapidly. ${ }^{20}$ Either slightly before or concurrent with most troughs, there were small increases in government spending that were motivated almost entirely by the state of the economy. This suggests that the small falls in the high-employment surplus to GDP ratio around troughs documented in Section II were mainly the result of anti-recessionary policy.

The nature of these rapid spending changes, however, provides insight into why the changes were almost always quite small. The spending increases have typically been limited to actions that can be taken without Congressional approval, such as the acceleration of planned spending or tax refunds, or to actions for which Congressional approval is easy to obtain, such as the extension or expansion of unemployment insurance benefits. Since the number of such actions is inherently limited by the structure of the American government, it would be unrealistic to infer from the modest increases in spending around postwar troughs that equally rapid but more aggressive fiscal responses were possible.

The postwar record on major legislated anti-recessionary actions is complicated. There are no examples of major spending changes undertaken

${ }^{20}$ Bartlett (1993) reaches a more pessimistic conclusion about the speed with which even small fiscal actions can be taken. This difference is attributable mainly to the fact that Bartlett concentrates on public works programs, rather than on all spending and tax programs undertaken to end recessions. 
in response to recessions. There are, however, two times when taxes were cut in response to recessions: 1953 and 1975. (Taxes were also cut during the 1981 recession, but there is no evidence that this cut was motivated by the cyclical condition of the economy.) But both tax cuts were unusual in ways that may limit their relevance to other recessions. In 1953, the tax cut had already been passed before the recession began; all Eisenhower had to do was not ask that it be delayed. In 1975, the recession was particularly long; it had already been going on for over a year before any policy action was taken. A more positive interpretation of the 1975 experience, however, is that in response to a particularly severe recession, effective measures can eventually be taken. Consistent with this positive interpretation is the fact that the lag between when the tax cut was officially proposed and when the first rebate actually appeared was only five months.

Perhaps the most important lesson to be learned from this analysis is that most large fiscal actions have been taken in response to slow recoveries rather than to actual recessions. The 1964 tax cut, Nixon's "New Economic Policy," and Carter's tax cut and spending increases were all passed to increase growth in a sluggish, but basically healthy economy. This fact is significant because the potential for policy mistakes, for overheating the economy and generating inflation, is much higher for such policies than for those passed in the depth of recession.

Finally, the record of the specific actions taken in response to recessions suggests that focusing on the high-employment surplus is likely to lead, if anything, to overestimates of the extent of anti-recessionary fiscal stimulus. Most of the actions took the form of temporary tax cuts, temporary changes in transfers, and changes in the timing of disbursements, 
all of which may have much smaller effects than long-lasting changes in purchases or taxes.

\section{THE CONTRIBUTION OF POLICY TO RECOVERIES}

As Sichel (1992) and Beaudry and Koop (1993) document, recessions are typically followed by periods of very rapid growth. For the eight recessions since 1950, real growth in the four quarters after the trough has averaged $4.6 \%$, and has exceeded the average annual postwar growth rate of $2.75 \%$ in every recovery except the current one. ${ }^{21}$ In this section we attempt to measure the contribution of policy to this spurt of rapid growth following troughs. In particular, we ask whether in the absence of policy actions, output growth after troughs would have continued to be negative, been equal to its average postwar value, or been even higher than it actually was.

To measure the role of policy, it is clearly not enough to just establish how monetary and fiscal policy changed during recessions and recoveries; we also need estimates of the magnitude and timing of the policies' effects. Therefore, in this section we construct such estimates and analyze their implications. We do not attempt to shed new light on the underlying question of whether monetary and fiscal policy have real effects.

${ }^{21}$ We calculate average growth over the period 1953:2 to 1993:2, which is the sample period used in our subsequent calculations. Throughout, percentage changes are computed as changes in logarithms. 
For this exercise we take it as given that policy affects output, and seek to provide plausible estimates of the size of those effects.

\section{A. Estimating the Effects of Policy}

\section{Baseline Policies}

Any description of how policies have affected the course of the economy must compare the economy's actual behavior with how it would have behaved if policies had followed some baseline paths. Thus the analysis requires specifying baseline policies. We take as our baselines a constant real federal funds rate and a constant ratio of the high-employment surplus to trend GDP. Thus we are attempting to estimate the contributions of changes in the real funds rate and in the ratio of the high-employment surplus to trend GDP to the path of real output.

These baseline policies are approximately feasible. Unpredictable movements in expected inflation, and in receipts and expenditures for a given level of activity, make it impossible for policy-makers to keep the real

funds rate and the high-employment surplus to trend GDP ratio exactly constant. On a quarterly basis, however, these shocks are likely to be small. This would not be true of some other potential baselines; quarterly shocks to the money supply and to the unadjusted deficit, for example, appear to be large.

Over the longer term, there is no reason that fiscal policy cannot keep the high-employments surplus to trend GDP ratio roughly constant. Monetary policy, on the other hand, cannot keep the real interest rate above or below its long-term equilibrium level indefinitely without causing 
explosive inflation or deflation. But movements in the sustainable level of the real interest rate are likely to be gradual. Thus attributing movements in the real interest rate that are in fact due to changes in its sustainable level to changes in monetary policy will not have a large effect on the analysis of the sources of short-run output movements. ${ }^{22}$

\section{Approaches to Estimating the Effects of Policy}

We estimate the effects of monetary and fiscal policy in three ways. The first two approaches are based on simple regressions, and the third is based on a large macroeconomic model.

Our first regression is an OLS regression of real GDP growth on eight lags of the change in our estimate of the real federal funds rate and on the current and eight lags of the change in the high-employment surplus to GDP ratio. We also include a constant, a dummy variable for the post1973 period (to account for the productivity growth slowdown), and eight lags of the dependent variable. ${ }^{23}$

22 This would not be true if we took a corstant nominal funds rate as our baseline. Attempting to peg the nominal rate at an unsustainable lcvel would lead to explosive movements in inflation, the real rate, and output. Thus attributing shifts in the nominal rate that are in fact due to changes in its sustainable level to changes in monetary policy would have very large effects on the analysis of the sources of output movements.

${ }^{23}$ We exclude the current value of the change in the real funds rate on the grounds that the real rate is likely to respond to output movements within the quarter. Since this appears less likely with the high-employment surplus to GDP ratio, we include the contemporaneous value of that variable. Treating the two policy variables symmetrically has little effect on the results, however. 
The OLS estimates are likely to provide conservative estimates of the effects of changes in the real interest rate. Most importantly, if the Federal Reserve changes the real funds rate on the basis of information about future output movements beyond that contained in the right-hand side variables of the regression, the changes in the real rate will be positively correlated with the crror term. As a result, the OLS estimates will be biased upward (that is, toward zero). Since, as Section III describes, monetary policy responds very rapidly to economic developments, this effect is likely to be present to some extent. Similarly, any additional information that consumers have about future output movements will cause the real rate to rise before increases in output, again biasing the OLS estimates of the effects of changes in the real rate toward zero.

Contemporaneous interaction between changes in the real rate and output growth has more complex effects on the OLS estimates. Since simple examples suggest that such interaction is likely to also bias the estimates toward zero, and since the reaction of output to the real interest rate within the quarter is likely to be small in any event, this effect is unlikely to reverse the effects of the other biases. ${ }^{24}$

Thus the OLS estimates seem much more likely to understate than

24 Suppose the true model is $\Delta y_{t}=a_{0} \Delta r_{t}+a_{1} \Delta r_{t-1}+b \Delta y_{t-1}+\varepsilon_{t}^{y}$, $\Delta \mathrm{r}_{\mathrm{t}}=\alpha_{0} \Delta \mathrm{y}_{\mathrm{t}}+\alpha_{1} \Delta \mathrm{y}_{\mathrm{t}-1}+\beta \Delta \mathrm{r}_{\mathrm{t}-1}+\boldsymbol{\varepsilon}_{\mathrm{t}}$, where the $\varepsilon^{\prime} \mathrm{s}$ are independent whitenoise shocks, $a_{0}$ and $a_{1}$ are negative, $\alpha_{0}$ is positive, $b$ is positive (reflecting the positive serial correlation of output growth), and $\beta$ is negative (reflecting the negative serial correlation of changes in the real interest rate). For this case, one can show that the true effect of a change in $\Delta r$ on output growth in the subsequent period is larger (in absolute value) than what one would obtain from an OLS regression of $\Delta y_{t}$ on $\Delta r_{t-1}$ and $\Delta y_{t-1}$. 
overstate the effects of changes in the real funds rate. Since there are important sources of variation in real interest rates, such as concern about inflation and political considerations, that are not likely to be substantially correlated with sources of output movements not included in the regression, the bias may not be serious. And for fiscal policy, where major policy shifts appear to require at least several quarters to implement, and where there are many important sources of variation in policy other than economic conditions, significant correlation with the error term appears unlikely. Thus for fiscal policy the bias from using OLS is likely to be small.

Because of the potential bias of the OLS estimates, our second set of estimates of policies' effects are derived from IV estimation of the regression above, with the changes in the real rate treated as endogenous. As instruments, we employ the Romer and Romer $(1989,1994)$ and Boschen and Mills (1992) indexes of Federal Reserve policy. We use 16 lags both of the Romer-Romer index and of the change in the Boschen-Mills index.

The Romer-Romer index is a simple dummy variable equal to one on dates of apparent shifts by the Federal Reserve to policies designed to reduce inflation from its current level. Because these shifts to antiinflationary policy appear to be largely the result of changes in tastes, and not responses to additional information about future output movements, the index should be essentially uncorrelated with the error term of the regression. Thus the Romer and Romer dates should allow the IV regression to estimate the output effects of interest rate changes. The Boschen-Mills index described in the previous section is a less-than-ideal instrument because Boschen and Mills do not distinguish Federal Reserve actions that are independent of the economy from those that are responses 
to the predicted behavior of the economy. However, if one believes that most changes in stated Federal Reserve intentions represent independent policy shifts, then this index is a useful instrument for isolating the effects of policy-generated changes in interest rates.

Both the OLS and IV regressions are estimated over the period 1957:2 to 1988:4; the sample period is dictated by the availability of the Boschen-Mills index. To derive policy multipliers from these regressions, we use the coefficient estimates to calculate the dynamic multipliers for a one percentage point fall in the real federal funds rate and a one percentage point fall in the high-employment surplus to GDP ratio.

Our third set of estimates of policies' effects are from the Data Resources Incorporated (DRI) model of the U.S. economy. Using a large macroeconomic model has the advantage that it incorporates a great deal of information and judgment. It has the disadvantages, however, that it is much less transparent than the regressions and that its implications may reflect the model-builders' priors rather than characteristics of the data.

For monetary policy, the experiment we consider in the model is a permanent one percentage point change in the real federal funds rate with the parameters governing fiscal policy held fixed. For fiscal policy, we consider a permanent change in personal income taxes of one percent of GDP with the real funds rate held fixed. ${ }^{25}$

${ }^{25}$ For fiscal policy, we also investigated averaging the multipliers for a change in taxes with those for a change in government purchases. This resulted in a considerably larger effect in the quarter of the policy change and had little effect thereafter. Because most major postwar antirecessionary fiscal actions have taken the form of changes in taxes and 


\section{Results}

Figure 3 shows the multipliers for monetary policy implied by the two regressions and by the DRI model. The OLS regression implies that a permanent one percentage point fall in the real funds rate raises real GDP by $1.7 \%$. Most of this effect comes between the second and fifth quarters after the increase. As one would expect, the IV regression implies a somewhat larger impact. The overall effect is now a rise in real GDP of 3.6\%; the timing is similar to that with OLS. ${ }^{26}$ The DRI model implies a rise in real GDP of $1.1 \%$, with most of the effect coming between one and four quarters after the change.

Figure 4 shows the estimated multipliers for fiscal policy. The OLS regression implies that a permanent fall of one percentage point in the ratio of the high-employment surplus to trend GDP raises output by $1.1 \%$. The effect occurs gradually over about ten quarters. The IV estimates imply that the effects of lowering the surplus to GDP ratio are small and irregular. Taken literally, the estimates imply that fiscal policy has essentially no effects. However, because the standard errors are large, the IV regression

transfers, we focus on the multipliers for a change in taxes.

26 We also estimated the IV multipliers using as instruments only the Romer-Romer index and the exogenous right-hand side variables. The results are very similar to those shown in Figure 3. The implied multiplier for a one percentage point rise in the real federal funds rate reaches a maximum impact on real GDP of 4.3 percent after 12 quarters; the timing is the same as that for the OLS and basic IV regressions. Because the Romer-Romer index is a dummy equal to one on only a small number of dates, the point estimates for the limited IV regression are substantially less precise than those from the standard version. 
does not provide strong evidence against conventional views of the effects of fiscal policy. For example, the two standard error confidence interval for the sum of the coefficients on the surplus to GDP ratio is $(-1.59,1.70)$; for comparison, the OLS estimate is -0.74 . We therefore do not place great emphasis on the point estimates of the effects of fiscal policy from the IV regression. Finally, the DRI model implies that the effect of a fall of one percentage point in the surplus to GDP ratio on real GDP peaks after four quarters at $1.4 \%$ and then gradually declines.

\section{B. Implications for the Source of Recoveries}

Table 6 summarizes the implications of these estimated multipliers for the sources of output growth in the four quarters after troughs. Specifically, for each of the three sets of multipliers, the table reports the implied average contributions during these periods of macroeconomic policies and other factors. The policy contributions are divided both according to whether they reflect monetary or fiscal policy and according to whether they reflect actions before the peaks in real output or actions afterward. In addition, the contributions of fiscal policy are divided into the effects of automatic and discretionary policy. The reason for separating the effects of pre-peak and post-peak policies is that the multipliers suggest that the lags in the effects of monetary policy are sufficiently long that the shifts to tighter monetary policy before peaks continue to depress growth even after troughs. Thus what we need to understand is not simply why output growth is above normal in recoveries, but why it is above normal despite the previous monetary tightenings.

All three sets of estimates imply that the reductions in real interest 
rates after peaks are crucial to recoveries. The OLS multipliers imply that these reductions have added an average of 1.6 percentage points to real growth during the first year of recoveries, the IV multipliers imply that they have added 3.0 percentage points, and the DRI multipliers imply that they have added 1.5 percentage points. Thus the estimates imply that the declines in real interest rates in recessions are large enough, and their effects occur quickly enough, that they play a critical role in the rapid growth during recoveries. Since average output growth in the year following troughs is $4.6 \%$, the OLS estimates imply that without these declines, growth in the year after troughs would average only $3.0 \%$; the IV estimates imply that it would average just $1.6 \%$; and the DRI estimates imply it would average only $3.1 \% .^{27}$

The OLS and DRI estimates imply that discretionary fiscal

27 Our calculations assume that the changes in the real funds rate resulting from the Federal Reserve's consistent responses to recessions have the same real effects as other movements in the real funds rate. This appears to be a reasonable approximation, for two reasons. First, since the Federal Reserve adjusts the real funds rate rapidly to economic developments, both the recession-related and the remaining part of movements in the real funds rate have a large unanticipated component to them. Second, for the real interest rate (in contrast to the money supply), there is no clear reason for unanticipated and anticipated changes to have very different effects. As described in Section II, the fact that systematic Federal Reserve policy affects the nominal funds rate, together with the fact that the direction of the effect is that expansionary policy lowers the nominal rate, strongly suggests that the systematic component of policy affects the real rate as well. It is possible, of course, that a larger movement in the money supply is needed to bring about a given change in the real funds rate when the movement is the result of systematic policy; but this is not relevant to our calculations. 
expansions after peaks contribute moderately to growth (not surprisingly, the IV estimates imply that the effect is negligible). In both cases, however, the majority of the estimated effect comes from the recovery from the 1973-75 recession. In addition, because the changes in discretionary fiscal policy in recessions have consisted disproportionately of temporary changes in taxes and transfers, the multipliers are likely to overstate their effects. Thus discretionary fiscal policy has played at most a small role in recoveries.

Our estimates imply that automatic changes in fiscal policy are more important. As described in Section II, there are consistent and substantial changes in the automatic component of the surplus during recessions. As a result, the OLS estimates suggest that the automatic movements in fiscal policy after peaks add an average of $0.6 \%$ to growth in the first year of recoveries, and the DRI model suggests that they add $0.9 \%$.

Together, these results imply that policies undertaken during recoveries are crucial to strong recoveries. All three sets of estimates suggest that without these policies, growth during the first year of recoveries would be anemic. The OLS estimates imply that it would have averaged $2.1 \%$, the IV estimates imply $2.0 \%$, and the DRI estimates imply $1.4 \%$. Our results suggest that the main source of the weak growth that would occur without the post-peak changes in policy is the monetary tightening that usually occurs before peaks. The first column of Table 6 suggests that prepeak monetary policy reduces growth in the year after troughs by roughly $1 \%$.

Non-policy factors appear to have little effect on growth in the year following troughs. The final column of Table 6 shows the amount of aboveaverage growth not accounted for by pre-peak or post-peak policies. While 
this residual varies somewhat depending on the multipliers used, it is typically small, implying that growth would have been approximately average during the first year of recoveries in the absence of policy changes. Thus nothing in our analysis suggests that output would continue to drop indefinitely without governmental intervention. Similarly, nothing suggests that the economy possesses strong self-correction mechanisms that would cause it to quickly make up the output losses that occur during recessions.

Considering slightly longer horizons strengthens the case that monetary policy is critical to recoveries. For example, output growth (at an annual rate) in the fifth and sixth quarters of recoveries averages only 0.1 percentage points above normal; but the OLS multipliers imply that postpeak monetary policies contribute 1.4 percentage points to annual growth in these quarters, the IV multipliers imply that they contribute 3.1 percentage points, and the DRI multipliers imply that they contribute 0.2 percentage points. $^{28}$

${ }^{28}$ We also investigated the implications of using multipliers from the MPS model maintained by the Federal Reserve Board. The MPS model implies very gradual, but very persistent, effects of monetary policy on real output. This response occurs mainly because the nominal long-term rate is assumed to adjust gradually to the nominal short-term rate. This gradual adjustment causes the real long-term rate to fall essentially linearly in response to a permanent change in the real funds rate. As a result, the change in the funds rate has very little effect on output in the first year, and a nearly permanent effect on output growth thereafter. The model therefore suggests a very different view of the source of recoveries than any of the estimates considered in the text. The MPS multipliers, like the OLS and DRI ones, imply that fiscal policy contributes moderately. But the extreme lags in the effects of monetary policy in the model mean that the monetary expansions undertaken during recessions have only a modest effect on 


\section{Implications of an Alternative Baseline}

The preceding analysis takes a constant real federal funds rate as the baseline monetary policy, and therefore describes output movements resulting from changes in the real funds rate as being due to monetary policy. But there are other possible baselines. In a conventional textbook model where the Federal Reserve is targeting the growth rate of the money supply, nominal interest rates would decline in a recession because of the fall in income and because of the increase in the real money supply resulting from the fall in inflation. The effect on real interest rates would be mitigated, however, by the decline in expected inflation.

The magnitude of these effects depends on the interest and income elasticities of money demand. Following the standard practice in the money demand literature, assume that money demand takes the form

$$
\ln m_{t}=a+b \ln y_{t}-c \ln i_{t}+-d \dot{\pi}_{t}+\lambda \ln m_{t-1}
$$

where $m_{t}$ is real money balances, $y_{t}$ is real income, $i_{t}$ is the nominal interest rate, and $\pi_{\mathrm{t}}$ is inflation. Equation (1) implies that a decline in $\mathrm{y}$ with $\mathrm{m}$ held fixed reduces $\ln \mathrm{i}$ by $(\mathrm{b} / \mathrm{c}) \Delta \ln \mathrm{y}$, and therefore reduces $\mathrm{i}$ by approximately (b/c) $[\Delta \ln y]$ i. Similarly, it implies that a fall in the price level with the nominal money stock held fixed reduces $i$ by approximately $(1 / c)(1-d)$. $[\Delta \ln p] i$ in the initial period and $[(1-\lambda) / c][\Delta \ln p] i$ in subsequent periods. Goldfeld and Sichel (1990), Judd and Scadding (1982), and others suggest

growth during the first year of recoveries. As a result, the model implies that non-policy factors are the critical source of recoveries. 
that reasonable values of the parameters in (1) are $b=0.12, c=0.05$, $\mathrm{d}=0.7$, and $\lambda=0.8$. These values imply long-run income and interest elasticities of 0.60 and -0.25 , respectively.

To estimate the effect of the recession on interest rates when money growth is held fixed, we need measures of the falls in output, prices, and expected inflation due to the recession. We compute the fall in output between the peak and the quarter following the trough due to the recession (the $\Delta$ ln y term in the expression above) simply as the sum of the shortfalls of quarterly output growth from its average value of $2.75 \% / 4$, or $0.69 \%$. These values of the change in $y$, together with the estimates of $b$ and $c$ and the actual values of the nominal interest rate, imply that if the Federal Reserve did not adjust the money growth rate, the falls in real income would reduce the nominal interest rate by an average of 0.6 percentage points over the period from the peak to one quarter after the trough.

To find the effect of the recession on the price level, we compare the actual path of the price level with what would have occurred if inflation had simply held steady at the value of expected inflation implied by our estimated real federal funds rate as of the peak quarter. These estimates imply that the increases in the real money supply coming from the declines in inflation reduce the nominal interest rate by an average of 0.5 percentage points. Thus the textbook self-correction mechanism of downward pressure on prices increasing real money balances and therefore lowering interest rates accounts for only a small part of the interest rate declines during 
recessions. $^{29}$

Finally, the estimates of expected inflation implied by our real funds rate series suggest that expected inflation declines by an average of 1.4 percentage points between the peak and the quarter after the trough. The fact that the direct effects of the declines in expected inflation more than offset the effects of the increases in the real money stock resulting from the falls in inflation is consistent with the evidence of De Long and Summers (1986) that price flexibility is on net destabilizing in the U.S. economy.

Combining these three figures, our results suggest that if the Federal Reserve were holding money growth fixed, the behavior of income, prices, and expected inflation would lead to only small falls in the nominal interest rate between the peak and the quarter after the trough, and have essentially no effect on the real interest rate. Thus choosing a baseline for monetary policy that takes account of these effects would not affect our conclusion that monetary policy is the primary engine of recovery from recessions. ${ }^{30}$

${ }^{29}$ An alternative way of computing the effect of the recession on the price level would be to combine the figures for the decline in output with standard estimates of the Phillips curve (for example, Gordon, 1990). Doing this yields a slightly larger implied reduction in nominal interest rates.

${ }^{30}$ By describing any changes in the real interest rate that are not due to changes in income, prices, and expected inflation as changes in monetary policy, the baseline policy implicit here is money targeting that accommodates any shifts in the money demand function. A natural alternative choice of the baseline would be pure money targeting. We do not pursue this possibility for two reasons. First, there have been large shifts in money demand, most of which were largely accommodated by the Federal Reserve. Second, the results are potentially sensitive to the 


\section{STABILIZATION AND PERSISTENCE}

Our analysis of the contribution of macroeconomic policy to output growth can be used to address two other issues. First, we can examine the overall role of macroeconomic policy in economic stabilization. Even if policy has contributed to recoveries, it is useful to consider its effects in other periods. Second, we can investigate the extent to which the persistence of overall output movements derives from the persistence of policy changes and their effects.

\section{A. The Overall Record of Stabilization Policy}

Our estimates of the contributions of policy to output growth can be used to construct estimates of what the path of real output would have been if policy had held the real interest rate and the high-employment surplus to GDP ratio constant. Figure 5 shows the implied paths of real output under policies of a constant high-employment surplus to GDP ratio and a constant real funds rate, together with its actual path, for the three sets of multipliers. Since, as described above, monetary policy cannot in fact hold the real rate constant indefinitely, no great significance should be attached to the longer-term movements in the difference between the implied and actual paths. But the shorter-term swings can be interpreted as largely representing the effects of policy.

The OLS multipliers suggest that departures from the baseline

specification of what it means for the Federal Reserve to continue with "normal" money growth during recessions. 
policies have generally made recessions more severe, and recoveries more rapid, than they otherwise would have been. The estimates imply, for example, that the 1960 and 1969 recessions would not have occurred at all under the baseline policies, and that the output declines in the 1973 and 1981 recessions would have been half as large as they actually were. These estimates suggest that the one major success of active policy occurred in the last few years: since growth has been weak despite a falling real funds rate, the estimates imply that there would have been a protracted and severe recession under the baseline policies.

The IV multipliers suggest a generally similar picture. They imply, however, that in addition to preventing a major downturn over the past few years, active policy prevented extended periods of approximately zero growth in the mid-1950s, mid-1970s, and mid-1980s. Finally, the DRI multipliers imply that the 1953 and 1960 recessions would not have occurred under the baseline policies, that the 1969 and 1973 recessions would have occurred later and been slightly more severe, and again that the 1990 recession would have been much longer and larger.

This overall record of stabilization policy suggests that policy, especially monetary policy, helped to both start and stop postwar recessions. Since both inflation control and output growth are generally considered valid goals of macroeconomic policy, it would be hard to find consensus that either of these uses of policy was inappropriate. Given that throughout most of our sample period inflation was at levels that (both at the time and in retrospect) were viewed as excessive, it is arguable that low output growth was likely to be needed at some time to reduce inflation. The only issues concern the timing and speed of disinflation. Similarly, when output growth 
is low and inflation is low or falling, most economists would probably agree that expansionary policy is appropriate. Thus the tightening and loosening of policy around recessions and recoveries are hard to question.

In contrast, expansionary policy taken in face of a strong economy and of inflation that is high or rising might be generally viewed as mistaken. By this standard, three times stand out as periods when policy was overly expansionary: $1967-68,1972$, and 1986-87. Growth was above normal in all three periods. Unemployment was also low to moderate in each case: $3.6 \%$ in $1967-68,5.5 \%$ in 1972 , and $6.5 \%$ in 1986-87. Yet both the OLS and IV multipliers imply that policy was adding considerably to real growth in all three periods. Averaged over these five years, the OLS multipliers imply that monetary policy contributed $1.2 \%$ to real growth and discretionary fiscal policy contributed $0.5 \%$. The same numbers for the IV multipliers are $2.4 \%$ for monetary policy and $0.2 \%$ for discretionary fiscal policy. The DRI multipliers also imply that monetary policy contributed substantially to growth in these years, with an average contribution of $0.6 \%$ per year. These multipliers imply, however, that discretionary fiscal policy had an offsetting effect of $-0.7 \%$, so that the overall contribution of policy was essentially zero. ${ }^{31}$

31 As Figure 4 shows, the DRI model implies that a decrease in the surplus to GDP ratio has a negative effect on growth beginning in the fifth quarter after the decrease. These delayed contractionary effects are the main source of the model's implication that fiscal policy reduced growth in 1967-68, 1972, and 1986-87. When these effects are omitted, the DRI multipliers imply that discretionary fiscal policy contributed just $-0.1 \%$ to average growth in these years. The delayed contractionary effects of fiscal policy are also the main source of the estimated moderate contribution of pre-peak automatic and discretionary fiscal policy to output growth in recoveries reported in Table 6. 
The nature of the expansionary policies differs across the episodes. The 1967-68 and 1986-87 episodes involved moderately stimulative policies at relatively late stages in expansions. The stimulus in the 1967-68 period stemmed from reductions in the high-employment surplus in 1965 and 1966 and from an absence of consistent changes in the nominal federal funds rate in the face of rising inflation over the period 1965-67. The stimulus in 1986 and 1987 was the result of a general downward trend in both the highemployment surplus and the nominal federal funds rate, together with slight upward movements in inflation. The 1972 episode, on the other hand, resulted from extremely expansionary monetary policy in the wake of the mild 1969 recession. In the three quarters after the recession ended in the second quarter of 1970 , the nominal federal funds rate fell from $7.88 \%$ to $3.86 \%$. It fluctuated irregularly over the next year, reaching a low of $3.54 \%$ in the first quarter of 1972. Since inflation was, if anything, rising over this period, the result was that monetary policy was extremely stimulative. Despite the differences in the nature of policy across these episodes, they are united by the fact that expansionary policies stimulated an already strong economy and thus set up the inflation that ultimately induced later tightenings.

\section{B. The Persistence of Output Fluctuations}

A large recent literature examines the persistence of output movements. The general conclusion of this research is that quarterly changes in real GDP are highly persistent. The usual presumption in interpreting these findings, either implicit or explicit, is that output movements driven by shifts in aggregate demand will not be highly persistent 
(see for example Nelson and Plosser, 1982, and Blanchard and Quah, 1989). As a result, the conclusion that has been drawn from these studies is that supply-side disturbances must be a crucial source of fluctuations.

Our examination of postwar monetary and fiscal policy and their contributions to output movements suggests that the presumption underlying this conclusion should be reexamined. There are extended periods when macroeconomic policy -- particularly monetary policy -- is either generally expansionary or generally contractionary. And our estimates of policies' effects imply that the impact of any given policy movement on the economy is quite protracted. Thus monetary and fiscal policies' contributions to output movements may be highly persistent.

To examine this issue formally, we perform a bivariate experiment analogous to the univariate one performed by Campbell and Mankiw (1987a). Campbell and Mankiw estimate some simple processes for overall output growth, and then use these processes to address the question of how forecasts of the path of output should be revised in response to an output innovation. Analogously, we decompose output growth into the estimated contributions of discretionary policy and of other factors, and then ask how one should revise the forecasted path of output in response to innovations in each of these two components.

Specifically, we estimate a bivariate vector autoregression (VAR) using these two variables with four lags, and then find the effects of shocks to each of the variables. The sum of a shock's effects on policy-related and non-policy related growth represents its effect on the path of output growth. Cumulating these growth effects then gives its effect on the path of the log of total output. 
The results suggest that output innovations stemming from macroeconomic policies have considerably more persistent effects than innovations coming from other sources. Consider for example the results when the OLS multipliers are used to estimate the component of output growth that is due to monetary policy and discretionary fiscal policy, and thus to decompose output growth into policy and non-policy components. The VAR implies that the overall output effect of a 1\% shock to the nonpolicy component of output peaks at $1.3 \%$ two quarters after the shock and then gradually declines. The effect returns to $1 \%$ after 6 quarters, and is $0.7 \%$ after 12 . This relatively low persistence occurs because the policy component of output growth responds negatively to the non-policy component: policy-makers respond to positive output innovations by tightening. The overall effect of $0.7 \%$ after 12 quarters, for example, reflects a contribution of $+1.5 \%$ from the non-policy component and an offsetting contribution of $-0.8 \%$ from the policy component.

The results imply that independent changes in the policy component of output growth, in contrast, have extremely persistent effects. A $1 \%$ innovation raises overall output by $2.3 \%$ after 4 quarters and $2.4 \%$ after 12 . This strong persistence arises both because the policy component of growth is highly serially correlated and because the non-policy component is essentially unresponsive to the policy component. The strong serial correlation of the policy component, in turn, stems from the facts that the estimated effects of real interest rate changes are quite protracted and that 
the real interest rate reverts to its mean only slowly. ${ }^{32}$

Using the IV and DRI multipliers to decompose output growth into the policy and non-policy components produces generally similar results. The IV multipliers imply that a $1 \%$ innovation to growth stemming from sources other than policy raises the level of output after 12 quarters by $0.8 \%$, while a $1 \%$ innovation to the policy component raises output after 12 quarters by $1.9 \%$. With the DRI multipliers, the figures are $1.2 \%$ and $2.4 \%$. Thus these alternative sets of multipliers continue to imply that the policyinduced output movements are considerably more persistent than other output movements.

Taken together, the results using all three sets of multipliers suggest that the source of the high degree of persistence of aggregate output fluctuations may be quite mundane. Rather than reflecting fundamental characteristics of fluctuations, it may simply reflect the fact that shifts in macroeconomic policy and their effects on the economy are often quite

${ }^{32}$ It is of course possible that the output effects of a shock to the policy component of output are eventually reversed. Indeed, our procedure for estimating the effects of policy imply that if shocks to the real interest rate and the surplus-to-GDP ratio are eventually completely undone, the long-run effect of a shock to the policy component of output is zero. As is well known, however, data from moderate time spans can shed little light on the effects of innovations at long horizons, and conventional estimates of the persistence of fluctuations (such as Campbell and Mankiw's) reflect effects at moderate rather than long horizons (see for example Christiano and Eichenbaum, 1990). For that reason, we focus on the effects of innovations over several years and make no attempt to estimate their effects at very long horizons. 
protracted. ${ }^{33}$

\section{CONCLUSIONS}

Our central conclusion is that monetary policy alone is a sufficiently powerful and flexible tool to end recessions. In nearly every postwar recession, policy-makers have been quick to discern the onset of recession and have responded to the downturn with rapid and significant reductions in nominal and real in'erest rates. Plausible estimates of the sizc and speed. of the effects of these interest rate cuts suggest that they were crucial to the subsequent recoveries.

Discretionary fiscal policy, in contrast, does not appear to have had an important role in generating recoveries. Fiscal responses to economic downturns have generally not occurred until real activity was approximately at its trough. In addition, these responses have generally been limited to small actions that could be undertaken without Congressional approval or for which Congressional approval was easy to obtain. As a result, our estimates suggest that fiscal actions have contributed only moderately to recoveries. Policy-makers have succeeded in making large adjustments in

33 Our results are consistent with the findings of Campbell and Mankiw (1987b) that the component of output movements that is correlated with movements in the unemployment rate is at least as persistent as general output fluctuations. West (1988) shows that a largely conventional model can imply that fluctuations driven by aggregate demand movements are relatively persistent. 
fiscal policy in response to recessions only in unusual circumstances. Thus the historical record contradicts the view that fiscal policy is essential to ending recessions or ensuring strong recoveries.

While monetary policy has been crucial to postwar recoveries, our results suggest that the overall record of discretionary monetary and fiscal policy is less impressive. One apparent error that has been made on several occasions is for policy-makers to become overly concerned about the possibility of weak growth during expansions, or excessively optimistic concerning the prospects for expansion without triggering inflation, and therefore to adopt excessively expansionary policies. The common pattern during recoveries is for there to be modest increases interest rates and little change in the high-employment surplus. However, in periods where policymakers have been concerned about low growth, they have often undertaken major fiscal expansions, or have kept nominal interest rates constant or declining in the face of rising inflation. On several occasions, such expansionary policies appear to have contributed substantially to abovenormal growth.

Finally, our analysis of the effects of policy may help to explain the persistence of movements in aggregate output. We find that the large degree of persistence of movements in real GDP appears to result to a considerable extent from extremely high persistence of the contribution of policy changes. Thus policy is not only the source of postwar recoveries, but also the source of the puzzling serial correlation in aggregate output. 


\section{REFERENCES}

Bartlett, Bruce. 1993. "How Not to Stimulate the Economy." The Public Interest (Summer): 99-109.

Beaudry, Paul, and Gary Koop. 1993. "Do Recessions Permanently Change Output?" Journal of Monetary Economics 31 (August): 149-163.

Bernanke, Ben S., and Alan S. Blinder. 1992. "The Federal Funds Rate and the Channels of Monetary Transmission." American Economic Review 82 (September): 901-921.

Blanchard, Olivier Jean, and Danny Quah. 1989. "The Dynamic Effects of Aggregate Demand and Supply Disturbances." American Economic Review 79 (September): 655-673.

Boschen, John F., and Leonard O. Mills. 1992. "The Effects of Countercyclical Monetary Policy on Money and Interest Rates: An Evaluation of Evidence from FOMC Documents." Manuscript, College of William and Mary (May).

Brunner, Karl, and Allen H. Meltzer. 1964. The Federal Reserve's Attachment to the Free Reserve Concept. U.S. Congress, House Committee on Banking and Currency, Subcommittee on Domestic Finance, 88th Congress, 2d Session. Washington, D.C.: U.S. Government Printing Office.

Campbell, John Y., and N. Gregory Mankiw. 1987a. "Are Output Fluctuations Transitory?" Quarterly Journal of Economics 102 (November): 857-880.

Campbell, John Y., and N. Gregory Mankiw. 1987b. "Permanent and Transitory Components in Macroeconomic Fluctuations." American Economic Review 77 (May): 111-117.

Carlson, Keith M. 1981. "Trends in Federal Revenues: 1955-86." Federal Reserve Bank of St. Louis Review 63 (May): 31-39. 
- 1987. "Federal Fiscal Policy Since the Employment Act of 1946." Federal Reserve Bank of St. Louis Review 69 (December): 14-25.

Christiano, Lawrence J., and Martin Eichenbaum. 1990. "Unit Roots in Real GNP: Do We Know and Do We Care?" Carnegie-Rochester Conference Series on Public Policy 32 (Spring): 7-62.

Cook, Timothy, and Thomas Hahn. 1989. "The Effect of Changes in the Federal Funds Rate Target on Market Interest Rates in the 1970s." Journal of Monetary Economics 24 (November): 331-351.

De Long, J. Bradford, and Lawrence H. Summers. 1986. "Is Increased Price Flexibility Stabilizing?" American Economic Review 76 (December): 1031-1044.

Goldfeld, Stephen M., and Daniel E. Sichel. 1990. "The Demand for Money." In Handbook of Monetary Economics, Vol. 1, 300-356. Benjamin M. Friedman and Frank H. Hahn, eds. Amsterdam: North-Holland.

Gordon, Robert J. 1990. "What Is New-Keynesian Economics?" Journal of Economic Literature 28 (September): 1115-1171.

Hinshaw, C. Elton. 1968. "The Recognition Pattern of the Federal Open Market Committee." In Forecasting and Recognizing Business Cycle Turning Points, 61-128. Rendigs Fels and C. Elton Hinshaw, eds. New York: Columbia University Press for NBER.

Judd, John P., and John L. Scadding. 1982. "The Search for a Stable Money Demand Function: A Survey of the Post-1973 Literature." Journal of Economic Literature 20 (September): 993-1023.

Karaken, John, and Robert M. Solow. 1963. "Lags in Monetary Policy." In Stabilization Policies, Commission on Money and Credit, 14-96. Englewood Cliffs: Prentice Hall.

Mishkin, Frederic. 1981. "The Real Interest Rate: An Empirical Investigation." Carnegie-Rochester Conference Series on Public Policy 15 (Fall): 151-200. 
Nelson, Charles R., and Charles I. Plosser. 1982. "Trends and Random Walks in Macroeconomic Time Series: Some Evidence and Implications." Journal of Monetary Economics 10 (September): 139-162.

Perry, George L., and Charles L. Schultze. 1993. "Was This Recession Different? Are They All Different?" Brookings Papers on Economic Activity (1): 145-211.

Romer, Christina D., and David H. Romer. 1989. "Does Monetary Policy Matter? A New Test in the Spirit of Friedman and Schwartz." NBER Macroeconomics Annual 3: 121-170.

Romer, Christina D., and David H. Romer. 1993. "Credit Channel or Credit Actions? An Interpretation of the Postwar Transmission Mechanism." Federal Reserve Bank of Kansas City, Changing Capital Markets: Implications for Monetary Policy: 71-116.

Romer, Christina D., and David H. Romer. 1994. "Monetary Policy Matters." Manuscript, University of California, Berkeley. Journal of Monetary Economics, forthcoming.

Sichel, Daniel F. 1992. "Inventories and the Three Phases of the Business Cycle." Mar'iscript, Federal Reserve Board (August).

U.S. Board of Governors of the Federal Reserve System. Annual Report. Various years.

U.S. Federal Open Market Committee of the Federal Reserve System. Minutes. Various years.

U.S. President. Economic Report of the President. Various years.

West, Kenneth D. 1988. "On the Interpretation of Near Random-Walk Behavior in GNP." American Economic Review 78 (March): 202209. 
TABLE 1

THE FEDERAL FUNDS RATE IN RECESSIONS

\begin{tabular}{ccccccccc}
\hline Date of Peak & $53: 2$ & $57: 3$ & $60: 1$ & $69: 3$ & $73: 4$ & $80: 1$ & $81: 3$ & $90: 2$ \\
\hline $\begin{array}{c}\text { Quarter Relative } \\
\text { to Peak }\end{array}$ & & & CHANGE IN NOMINAL RATE & (Percentage Points) \\
+1 & -0.03 & -0.01 & -0.24 & -0.04 & -0.67 & -2.36 & -3.99 & -0.08 \\
+2 & -0.03 & -1.37 & -0.76 & -0.37 & 1.93 & -2.85 & 0.64 & -0.42 \\
+3 & -0.37 & -0.92 & -0.64 & -0.69 & 0.84 & - & 0.29 & -1.32 \\
+4 & -0.39 & - & -0.29 & -1.18 & -2.74 & - & -3.51 & -0.56 \\
+5 & 0.22 & - & - & - & -3.04 & - & -1.72 & - \\
+6 & - & - & - & - & -0.88 & - & - & -
\end{tabular}

Cumulative Change,

Peak to Quarter

$\begin{array}{lllllllll}\text { After Trough } & -0.59 & -2.30 & -1.93 & -2.28 & -4.58 & -5.21 & -8.29 & -2.38\end{array}$

Quarter Relative

to Peak

$\begin{array}{lllllllll}+1 & 0.46 & -0.08 & -0.46 & -0.15 & -1.11 & -1.11 & -0.15 & -0.12 \\ +2 & 0.61 & -0.21 & 0.56 & 0.25 & 0.90 & -1.88 & -0.21 & -0.13 \\ +3 & 0.20 & -0.83 & -0.08 & -0.45 & 1.32 & - & 1.13 & -1.19 \\ +4 & -1.84 & - & -0.11 & -1.21 & -2.66 & - & -1.47 & -0.96 \\ +5 & -0.03 & - & - & - & -2.40 & - & -1.98 & - \\ +6 & - & - & - & - & -1.16 & - & - & -\end{array}$

Cumulative Change, Peak to Quarter

$\begin{array}{lllllllll}\text { After Trough } & -0.60 & -1.11 & -0.08 & -1.56 & -5.10 & -2.98 & -2.68 & -2.40\end{array}$

Note: Data for quarters after the first quarter after the trough are not reported. 
TABLE 2

THE FEDERAL FUNDS RATE IN RECOVERIES

$\begin{array}{llllllll}\text { Date of Trough } \quad 54: 2 & 58: 1 & 60: 4 & 70: 2 & 75: 1 & 80: 2 & 82: 3 & 91: 1\end{array}$

Quarter Relative to Trough

$\begin{array}{lllllllll}+2 & 0.02 & 0.38 & -0.27 & -1.14 & 0.74 & 6.02 & -0.63 & -0.22 \\ +3 & 0.29 & 0.84 & -0.06 & -1.71 & -0.75 & 0.72 & 0.15 & -0.83 \\ +4 & 0.16 & 0.40 & 0.72 & 0.71 & -0.59 & 1.21 & 0.66 & -0.79 \\ +5 & 0.43 & 0.52 & 0.00 & 0.91 & 0.37 & -0.20 & -0.03 & -0.25\end{array}$

Cumulative Change, 1 to 5 Quarters After Trough

Quarter Relative to Trough

$\begin{array}{lllllllll}+2 & 0.56 & -0.36 & -0.60 & 0.11 & 1.18 & 2.97 & 0.55 & -0.21 \\ +3 & -0.48 & 0.39 & -0.62 & -0.83 & -0.27 & 0.42 & 0.35 & -0.06 \\ +4 & 0.12 & 0.42 & 0.32 & -0.79 & 0.08 & 1.37 & -0.17 & -0.28 \\ +5 & 0.10 & 0.57 & 0.19 & 0.19 & 1.29 & -0.10 & 0.22 & -0.37\end{array}$

Cumulative Change,

1 to 5 Quarters After Trough
Change IN NOMINal RATE (Percentage Points)

$\begin{array}{llllllll}0.90 & 2.14 & 0.40 & -1.23 & -0.22 & 7.74 & 0.14 & -2.09\end{array}$

CHANGE IN REAL RATE (Percentage Points) 
TABLE 3

THE HIGH-EMPLOYMENT SURPLUS IN RECESSIONS AND RECOVERIES

\begin{tabular}{lllllllll} 
Date of Trough $\quad 54: 2$ & $58: 1$ & $60: 4$ & $70: 2$ & $75: 1$ & $80: 2$ & $82: 3$ & $91: 1$ \\
\hline
\end{tabular}

Quarter Relative

to Trough

\section{CHANGE IN RATIO OF HIGH-EMPLOYMENT SURPLUS} TO TREND GDP

(Percentage Points)

$\begin{array}{ccccccccc}-4 & - & - & - & - & 0.31 & - & - & - \\ -3 & 0.70 & - & - & - & 0.02 & - & -0.39 & - \\ -2 & -0.99 & - & -0.29 & 0.24 & 0.50 & - & 0.17 & 0.54 \\ -1 & 1.41 & -0.71 & -0.31 & -0.22 & -0.69 & - & -0.15 & -0.65 \\ 0 & 1.52 & 0.45 & -0.14 & -0.80 & -0.18 & 0.06 & -0.66 & -0.00 \\ +1 & 0.25 & -0.99 & -0.27 & -0.29 & -3.23 & -0.03 & -0.70 & -0.15 \\ +2 & 0.64 & -0.10 & -0.27 & 0.12 & 2.18 & -0.00 & 0.26 & 0.47 \\ +3 & 0.41 & -0.07 & 0.08 & -0.01 & -0.09 & 0.77 & -0.05 & -0.37 \\ +4 & 0.43 & 0.77 & -0.08 & -0.36 & 0.38 & -0.05 & -0.85 & -0.31 \\ +5 & -0.26 & 0.20 & -0.72 & 0.16 & 0.40 & -0.16 & -0.27 & -0.03\end{array}$

Cumulative Change, Peak to Quarter $\begin{array}{lllllllll}\text { After Trough } & 2.89 & -1.25 & -1.00 & -1.08 & -3.28 & 0.02 & -1.74 & -0.26\end{array}$ Cumulative Change, 1 to 5 Quarters After Trough $\begin{array}{llllllll}1.21 & 0.80 & -0.99 & -0.09 & 2.88 & 0.55 & -0.92 & -0.23\end{array}$

Note: Data for quarters prior to the peak are not reported. 
TABLE 4

THE AUTOMATIC SURPLUS IN RECESSIONS AND RECOVERIES

\begin{tabular}{|c|c|c|c|c|c|c|c|c|}
\hline Date of Trough & $54: 2$ & $58: 1$ & $60: 4$ & $70: 2$ & $75: 1$ & $80: 2$ & $82: 3$ & $91: 1$ \\
\hline
\end{tabular}

Quarter Relative

to Trough

$\begin{array}{llllllllll}-4 & - & - & - & - & -0.46 & - & - & - \\ -3 & -0.32 & - & - & - & -0.19 & - & -0.48 & - \\ -2 & -0.35 & - & -0.29 & -0.34 & -0.50 & - & -0.50 & -0.37 \\ -1 & -1.41 & -0.59 & -0.22 & -0.41 & -0.44 & - & -0.18 & -0.12 \\ 0 & -0.84 & -1.01 & -0.51 & -0.41 & -1.08 & -0.90 & -0.30 & 0.85 \\ +1 & 0.47 & -0.15 & -0.08 & 0.01 & 0.07 & -0.32 & -0.27 & -0.84 \\ +2 & -0.11 & 0.33 & 0.11 & -0.50 & 0.08 & 0.30 & -0.03 & -0.62 \\ +3 & 0.72 & 0.50 & 0.17 & 0.35 & 0.12 & 0.13 & 0.40 & -0.04 \\ +4 & 0.18 & 0.26 & 0.37 & -0.18 & 0.34 & -0.17 & 0.40 & -0.06 \\ +5 & 0.22 & 0.35 & 0.21 & -0.04 & 0.00 & 0.01 & 0.43 & -0.08\end{array}$

Cumulative Change,

Peak to Quarter

After Trough

Cumulative Change,

1 to 5 Quarters

After Trough

$-2.45$

$-1.76 \quad-1.09$

$-1.16$

$-2.60$

$-1.22$

$-1.74 \quad-0.49$ TO TREND GDP

(Percentage Points)

CHANGE IN RATIO OF AUTOMATIC SURPLUS$$
\text { , }
$$

$\begin{array}{llllllll}1.00 & 1.44 & 0.86 & -0.37 & 0.56 & 0.27 & 1.21 & -0.80\end{array}$

Notes: Data for quarters prior to the peak are not reported. 
TABLE 5

THE BOSCHEN-MILLS INDEX IN RECESSIONS AND RECOVERIES

\begin{tabular}{lllllllll}
\hline Date of Trough $\quad 54: 2$ & $58: 1$ & $60: 4$ & $70: 2$ & $75: 1$ & $80: 2$ & $82: 3$ & $91: 1$
\end{tabular}

Quarter Relative

to Trough

$\begin{array}{rrrrrrrrrr}-4 & - & - & - & - & 0.33 & - & - & - \\ -3 & 0.67 & - & - & - & -0.67 & - & 0.67 & - \\ -2 & 1.33 & - & 1.00 & 0.33 & 0.00 & - & 0.33 & \text { na } \\ -1 & 0.67 & 1.67 & 1.33 & 0.67 & 1.00 & - & 0.00 & \text { na } \\ 0 & 0.00 & 0.67 & 0.33 & 0.33 & 1.67 & 0.00 & 0.00 & \text { na } \\ +1 & 0.00 & 0.67 & 0.00 & 0.67 & 0.33 & 0.67 & 1.00 & \text { na } \\ +2 & -0.33 & -1.00 & -0.67 & 0.33 & 0.00 & 0.33 & 0.00 & \text { na } \\ +3 & -1.67 & -1.00 & -0.33 & 0.00 & -0.67 & 0.00 & -0.67 & \text { na } \\ +4 & -0.67 & 0.00 & -0.33 & -1.00 & -0.33 & 0.00 & -1.33 & \text { na } \\ +5 & -1.00 & -0.33 & -0.67 & 0.00 & -0.33 & 0.00 & 0.00 & \text { na }\end{array}$

Cumulative Change,

Peak to Quarter

After Trough

CHANGE IN THE BOSCHEN-MILIS INDEX

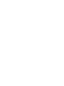


TABLE 6 ESTIMATES OF THE CONTRIBUTIONS OF MONETARY AND FISCAL POLICIES
TO GROWTH IN THE FIRST YEAR OF RECOVERIES

CONTRIBUTION TO GROWTH (Percentage Points)

\begin{tabular}{|c|c|c|c|c|c|c|c|}
\hline \multirow[b]{2}{*}{$\begin{array}{l}\text { Source of } \\
\text { Multipliers }\end{array}$} & \multicolumn{3}{|c|}{ Pre-Peak Policies } & \multicolumn{3}{|c|}{ Post-Peak Policies } & \multirow[t]{2}{*}{ Residual } \\
\hline & Monetary & $\begin{array}{l}\text { Discre- } \\
\text { tionary } \\
\text { Fiscal }\end{array}$ & $\begin{array}{l}\text { Auto- } \\
\text { matic } \\
\text { Fiscal }\end{array}$ & Monetary & $\begin{array}{l}\text { Discre- } \\
\text { tionary } \\
\text { Fiscal }\end{array}$ & $\begin{array}{l}\text { Auto- } \\
\text { matic } \\
\text { Fiscal }\end{array}$ & \\
\hline OLS & -0.92 & -0.18 & -0.01 & 1.59 & 0.25 & 0.63 & 0.45 \\
\hline IV & -2.05 & -0.00 & -0.03 & 3.00 & 0.02 & -0.41 & 1.30 \\
\hline DRI & -0.14 & 0.27 & 0.14 & 1.48 & 0.50 & 0.85 & -1.30 \\
\hline
\end{tabular}

Notes: The residual shows the component of the difference between mean growth in the year after troughs and average annual growth that is not accounted for by pre-peak and post-peak policies. The difference between mean growth after troughs and average annual growth is 1.82 percentage points; the rows may not add to this value due to rounding. 
FIGURE 1

NOMINAL AND EX ANTE REAL FEDERAL FUNDS RATES

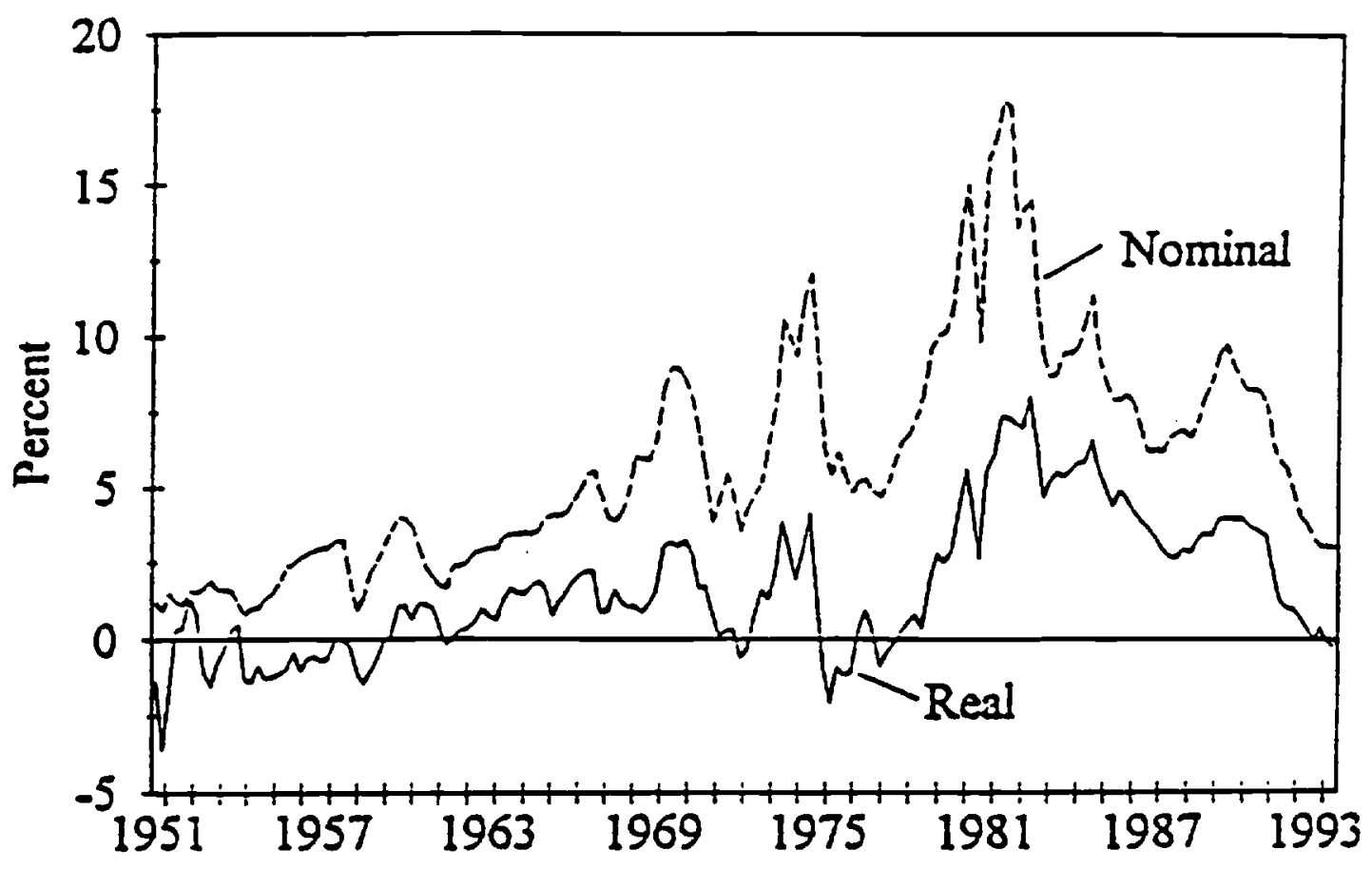


FIGURE 2

HIGH-EMPLOYMENT SURPLUS TO TREND GDP

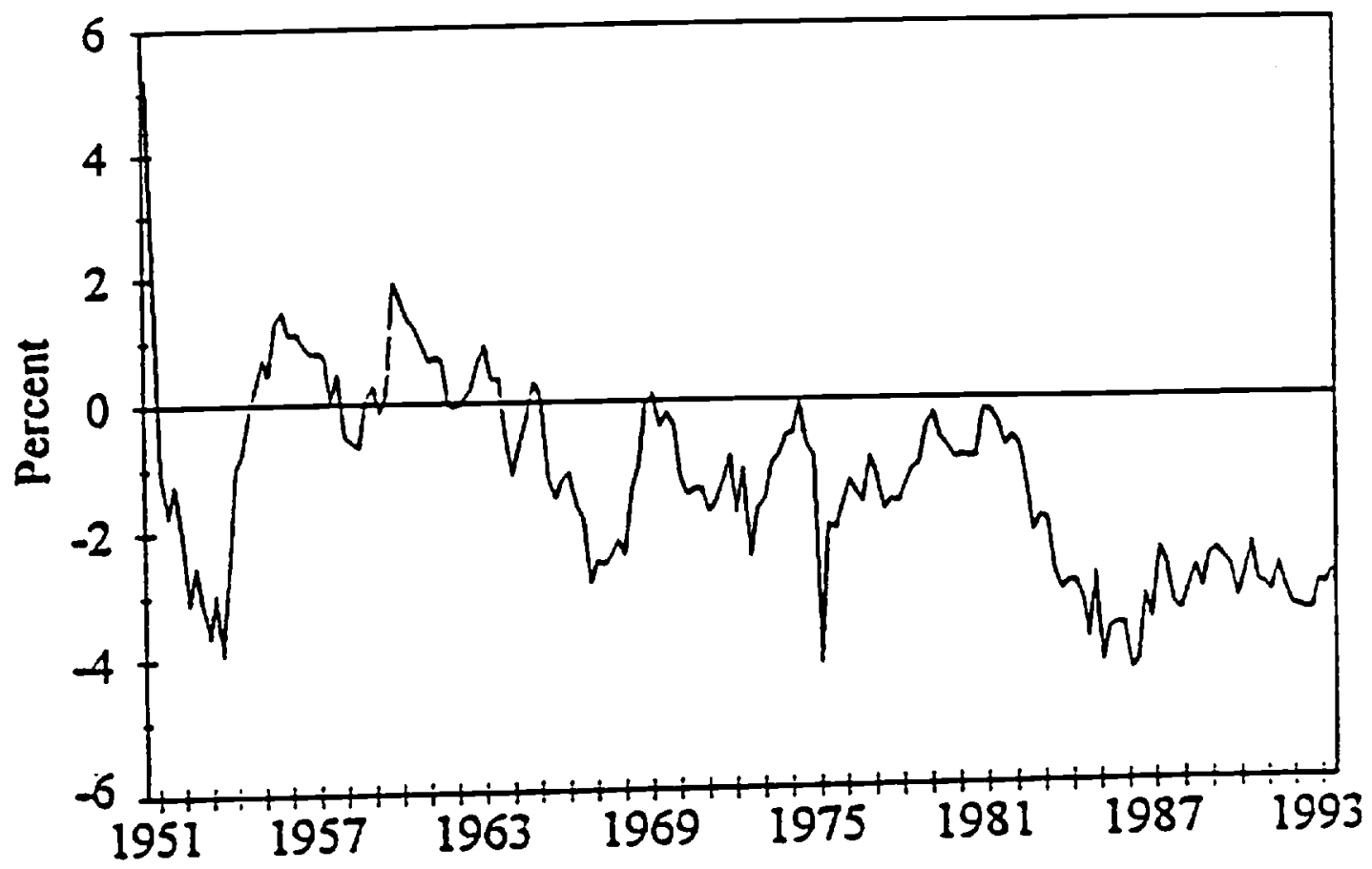


FIGURE 3

MULTIPLIERS FOR MONETARY POLICY

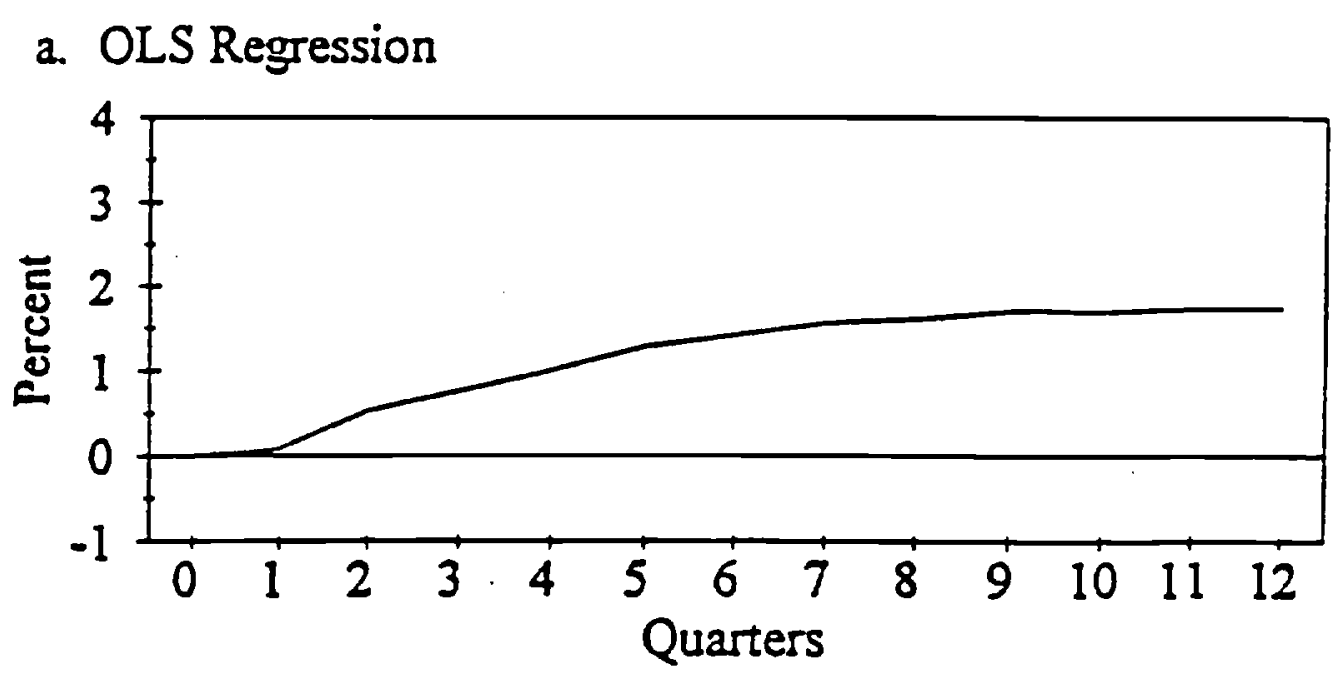

b. IV Regression

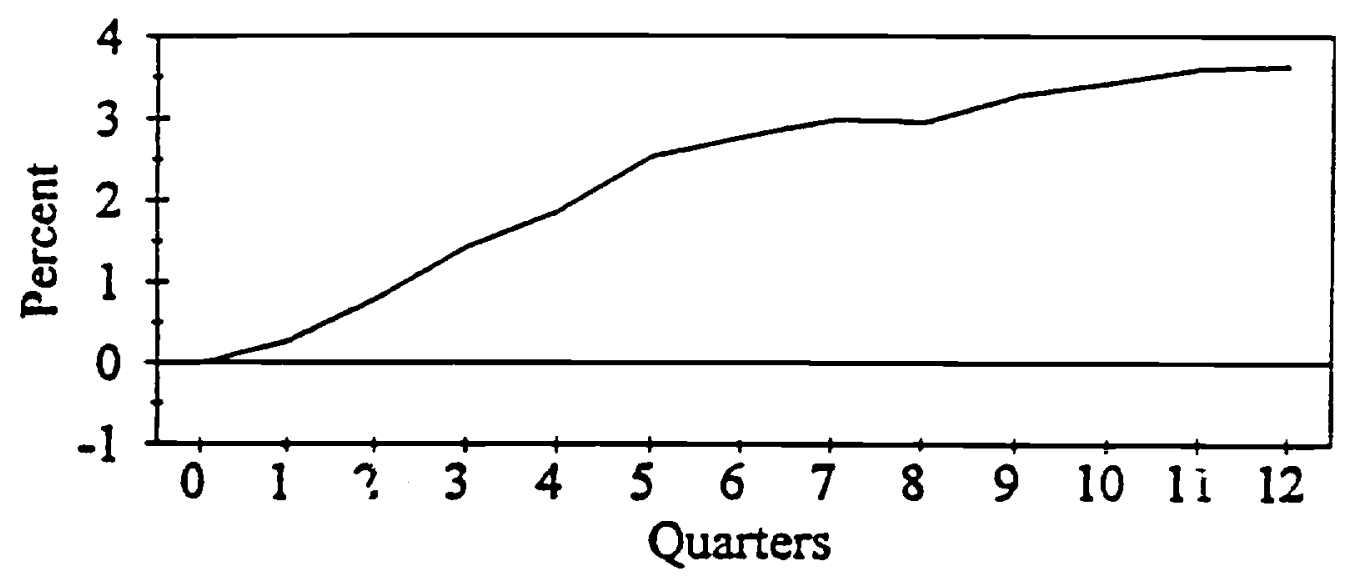

c. DRI Model

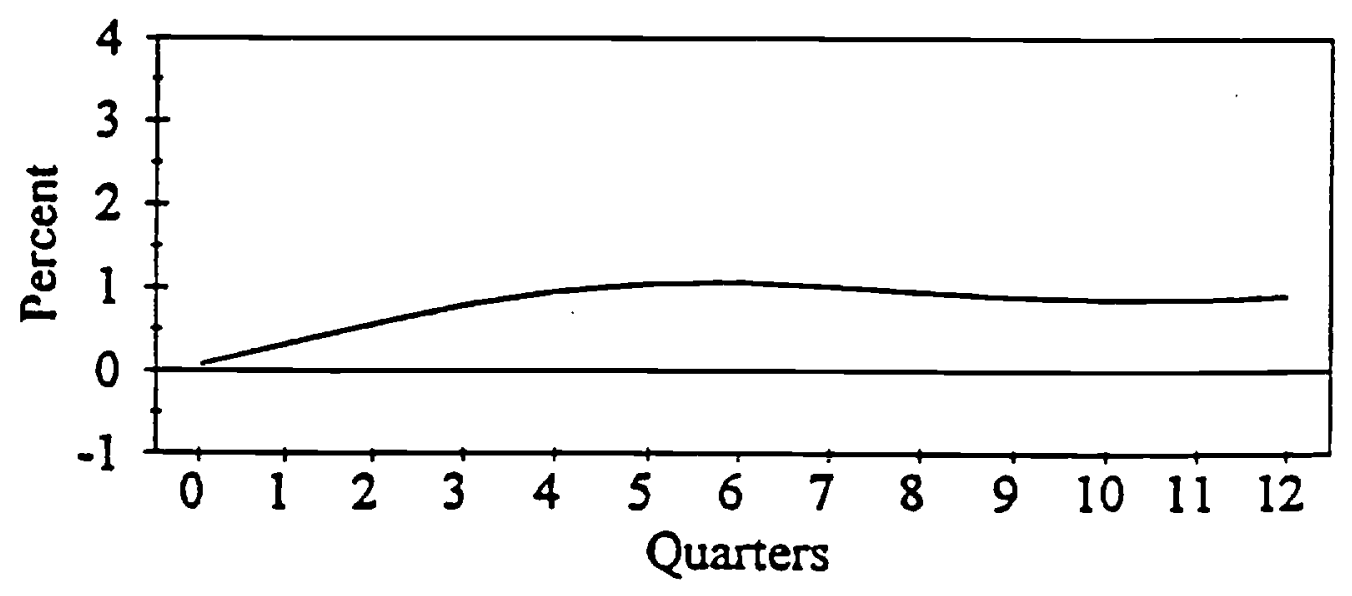


FIGURE 4

MULTIPLIERS FOR FISCAL POLICY

a. OLS Regression

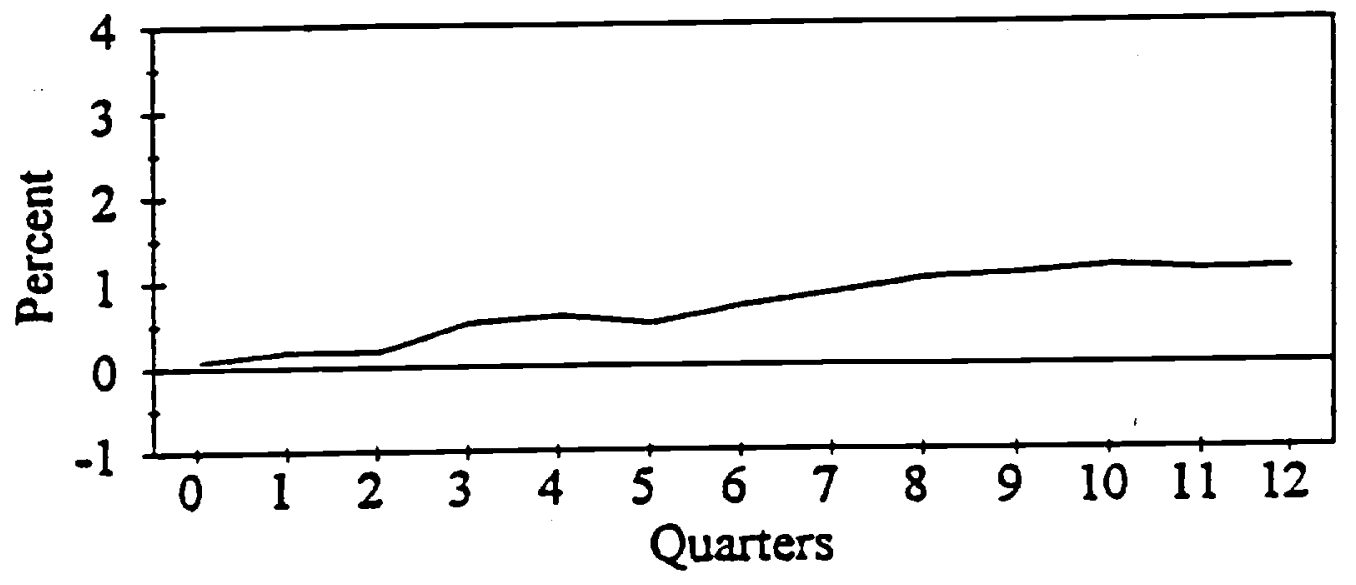

b. IV Regression

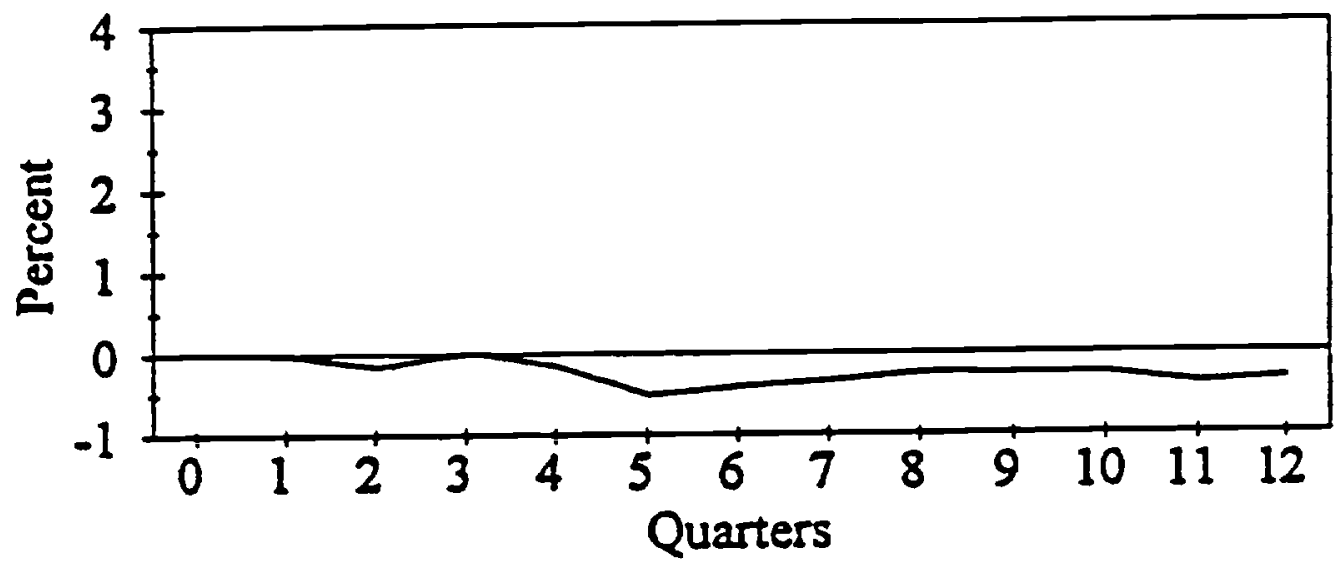

c. DRI Model

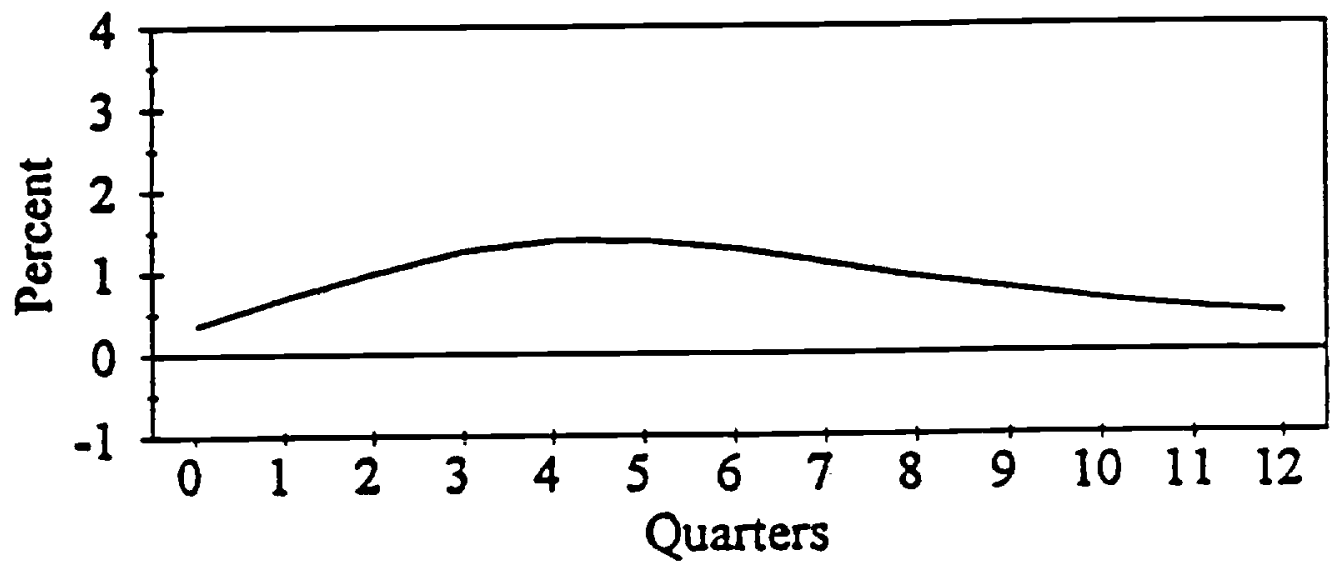


FIGURE 5

OVERALL EFFECTS OF ACTIVE POLICY

a. Multipliers from OLS Regression

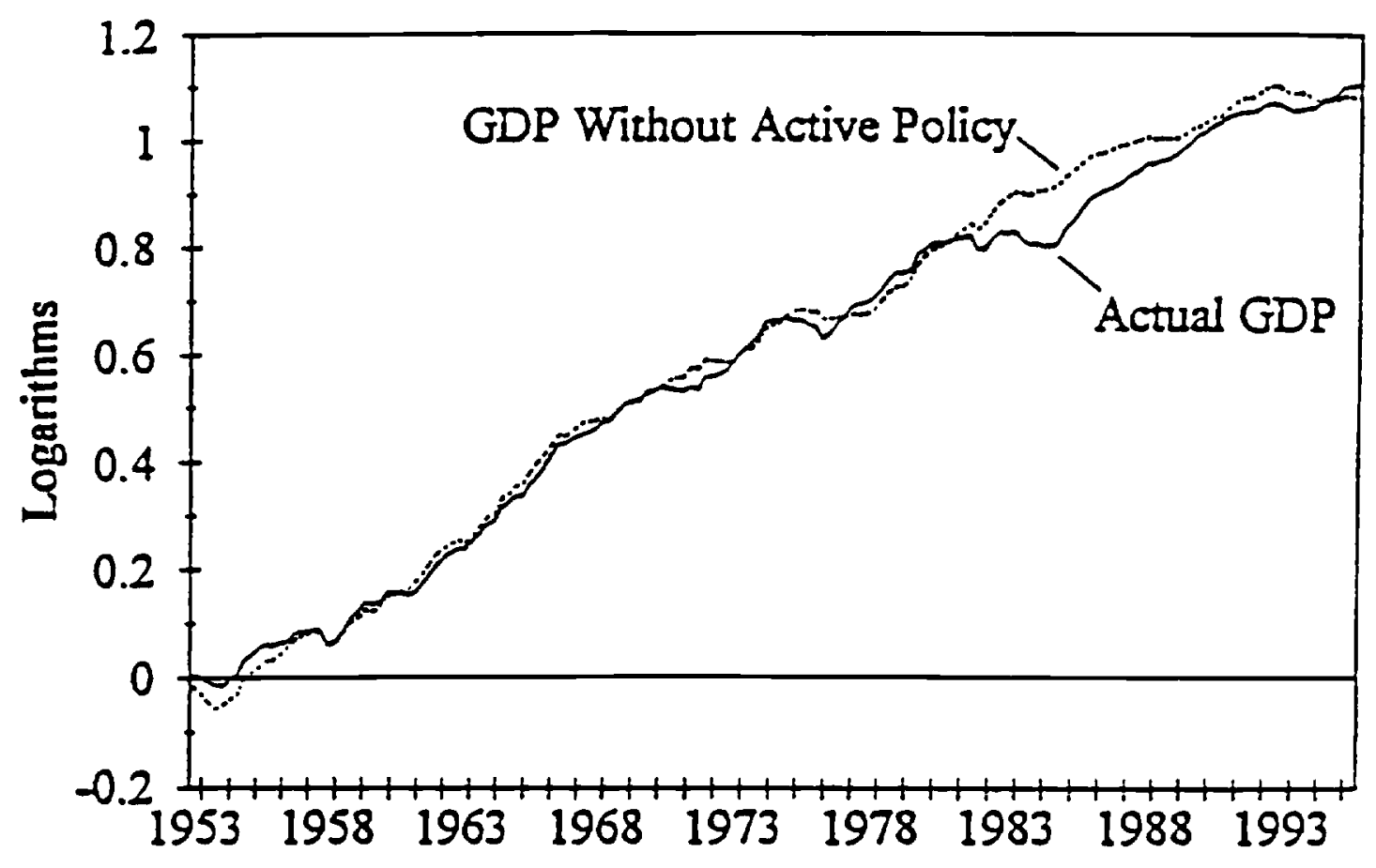

b. Multipliers from IV Regression

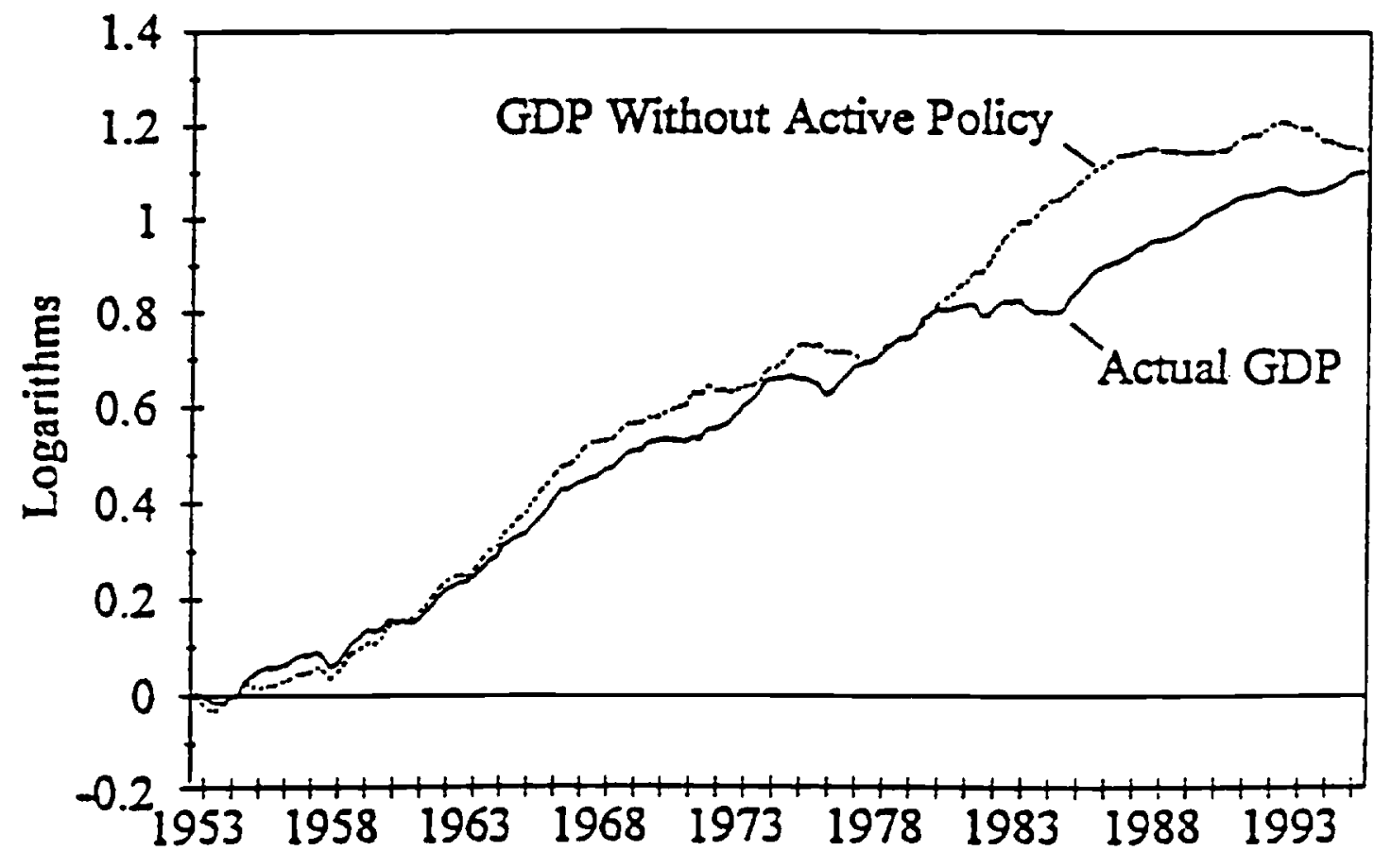


FIGURE 5 (CONTINUED)

c. Multipliers from DRI Model

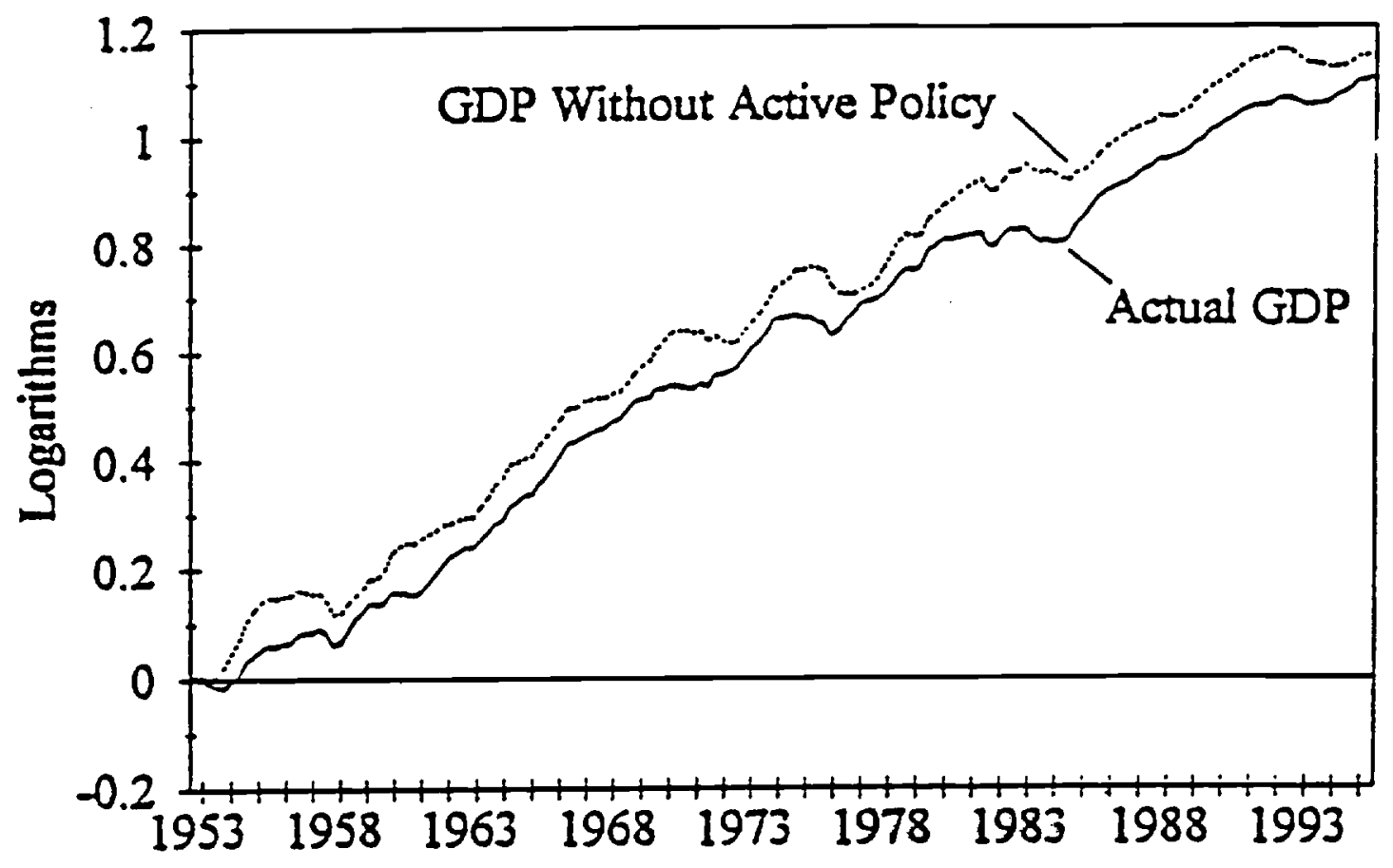

